\title{
EL REY EN LAS PARTIDAS DE ALFONSO X: SU VICARIATO DIVINO Y SU CARACTERIZACIÓN BAJO ESQUEMAS DE SACRALIDAD
}

\author{
POR \\ PLÁCIDO FERNÁNDEZ-VIAGAS ESCUdERO ${ }^{1}$ \\ Universidad de Sevilla
}

\begin{abstract}
RESUMEN
El presente artículo puede ser caracterizado como un trabajo de historia cultural. Su objetivo es interpretar el vicariato divino del rey proclamado en las Partidas en el entramado jurídico y simbólico del que formaba parte, así como estudiar los esquemas de sacralidad bajo los que fue caracterizada su figura en este código. Para ello, aprovecharemos las aportaciones de sociólogos y antropólogos, que arrojan luz sobre un tema que divide a la historiografía.
\end{abstract}

PALABRAS CLAVE: Alfonso X; Las Partidas; Castilla; Vicariato divino; Rey sagrado; Sacrilegio; Siglo XIII.

\section{THE KING IN THE PARTIDAS OF ALFONSO X: HIS DIVINE VICARIATE AND HIS CHARACTERIZATION IN TERMS OF SACREDNESS}

\begin{abstract}
This paper can be considered as a cultural history analysis. Its goal is to interpret the divine vicariate of the king proclaimed in the Partidas in its legal and symbolic framework, as well to study the sacred characters attributed to the king in this code. To do this, we will use contributions from sociologists and anthropologists, which shed light on an issue that divides the historiography. KEY WORDS: Alfonso X; The Partidas; Castile; Divine vicariate; Sacred King; Sacrilege; 13th century.
\end{abstract}

Cómo CITAR ESTE ARTículo / CitATION: Fernández-Viagas Escudero, P. 2017 «El Rey en las Partidas de Alfonso X: Su Vicariato Divino y su caracterización bajo esquemas de sacralidad». Hispania Sacra 69, 139: 61-80 doi: 10.3989/hs.2017.005

Recibido/Received 16-10-2015

Aceptado/Accepted 28-03-2016

\section{INTRODUCCIÓN}

Nuestro trabajo constituye un estudio de historia cultural, que se sumerge en la legislación histórica aprovechando las herramientas interpretativas del derecho y de otras ciencias sociales. Desde un punto de vista de aproximación general, nos inspiraremos en una técnica propia de la etnografía, aplicada con éxito en las últimas décadas en otras disciplinas. Nos referimos a la llamada descripción densa, que atiende no sólo al comportamiento humano, sino también al contexto cultural en el que está inserto, para explicar las estructuras conceptuales que funcionan en el campo social y otorgar el significado adecuado a las

\footnotetext{
1 placidofve@gmail.com / ORCID iD: http://orcid.org/0000-0002-5011-4749
}

acciones que en él ocurren. ${ }^{2}$ De esta manera, nos serviremos de una amplia variedad de fuentes, que nos permitirán interpretar el contenido de las Partidas dentro del discurso propagandístico de Alfonso $X$ y comprender las tramas de significación que conformaban el vicariato divino del rey.

No obstante, no nos ceñiremos a una sola aproximación, idéntica para los distintos puntos aquí tratados. Por el contrario, para un estudio específico respecto de determinados aspectos del discurso social, incorporaremos otros enfoques con una actitud abierta, en la medida en que se hayan mostrado eficaces a la hora de analizar aspectos concretos de la experiencia humana o que hayan aportado categorías útiles para su estudio. Así, particularmente, para discernir

2 Cf. Geertz 2003. Esta técnica se emparenta en el mundo del derecho con la llamada interpretación sociológica de las normas, que pretende interpretar éstas a la luz de la realidad social del momento. 
las diferencias entre lo sagrado y lo profano y comprender la naturaleza atribuida al rey en estas leyes, nos basaremos en estudios de sociólogos y antropólogos, cuyos resultados nos animan a abandonar los estrechos marcos conceptuales empleados por diversos historiadores de la monarquía castellana.

Los dos temas principales de este estudio son el de la figura del vicariato divino del rey y el de su caracterización bajo esquemas de sacralidad en las Partidas de Alfonso X. Ambas cuestiones podían haber sido objeto de un estudio separado, no obstante, dadas las múltiples interrelaciones que surgen en la explicación de las mismas, resulta conveniente abordarlas en un único trabajo que nos permita desarrollar las tramas simbólicas indispensables para su correcta interpretación y nos lleve a comprender la estrategia de dominación emprendida por el rey Alfonso sobre su pueblo.

\section{EL REY COMO VICARIO DE DIOS}

\subsection{Cuestiones principales}

Las Partidas se enmarcan en los inicios de un proceso histórico en el que, tras la difusión del derecho romano en los centros universitarios desde el siglo XII y su influencia en el derecho medieval, se afirma progresivamente el poder del monarca para dictar leyes generales y para aseverar su autoridad por encima de tradiciones locales y de otros poderes con los que entraba en competencia. ${ }^{3}$ En lo que respecta a la legislación de Alfonso X, este poder de dictar leyes tanto del emperador como del rey fue considerado como una competencia exclusiva de ambos ya en el Espéculo, ${ }^{4}$ con anterioridad al código de las Siete Partidas, que siguió esta misma línea al establecer que: «Emperador, o rey puede fazer leyes sobre las gentes de su señorio, e otro ninguno no ha poder de las fazer en lo temporal: fueras ende, si lo fiziesen con otorgamiento dellos». ${ }^{5}$

En este proceso de concentración del poder y de asunción de la potestad legislativa tuvo una influencia central la asociación de la figura del rey con unas imágenes que pretendían

3 Para un estudio de este fenómeno en la Baja Edad Media española, cf. Torrent 2013 y, más concretamente, respecto de la recepción del derecho romano en las Partidas, cf. Pérez Martín 1992. En todo caso, y mucho antes de este proceso histórico, en el Liber ludiciorum ya encontramos la vinculación entre el poder de hacer leyes y la figura del monarca, en los siguientes términos: «Ex mansuetudine etenim Principum oboritur dispositio legem ( )» (L. Iudiciorum 1,2,6).

4 Cf. Esp 1,1,3.

5 Cf. Part 1,1,12. La versión de las Partidas más reputada entre los historiadores del derecho es la de Gregorio López y a ella nos referiremos en el presente trabajo, salvo mención en contrario. Para un análisis de la cuestión de la exclusividad del rey Alfonso $X$ como generador del derecho, cf. Sánchez-Arcilla Bernal 2008-2009. Como veremos en el presente estudio, el poder temporal que tenía el rey sobre sus súbditos, que incluía su potestad de hacer leyes, residía desde el punto de vista teológico en la voluntad de Dios, que lo nombró su vicario en e reino. Sobre este tema, así como respecto de los fundamentos históricos de la potestad legislativa del rey de acuerdo con el derecho alfonsí, se reflexiona con acierto en Macdonald 1984: 34-35. Desde una perspectiva histórica más amplia, en cuanto al proceso en virtud del cua el monarca adquirió esta potestad en el siglo XIII, cuando se aprecia la transformación del rey juez al rey legislador, cf. Martínez 2010. reforzar su reconocimiento social y su capital simbólico ${ }^{6}$, con los que ubicarse por encima de otras instancias feudales. En esta línea hemos de interpretar la siguiente declaración de las Partidas: "Vicarios de Dios son los Reyes cada uno en su reyno, puestos sobre las gentes, para mantenerlas en justicia e en verdad quanto en lo temporal, bien assi como el Emperador en su imperio». ${ }^{7}$ Esta imagen del rey como vicario divino volvía a afirmarse en la ley XXVI, del título XIII, del libro II, que contenía otros dos arquetipos asociados a éste y configurados en clave teológica, el del rey como cabeza del reino y el del rey como elegido por la divinidad, bajo la siguiente formulación: «Otrosi como el coraçon esta en medio del cuerpo, para dar vida egualmente a todos los miembros del, asi puso dios al rey, en medio del pueblo, para dar egualdad e justicia a todos comunalmente, porque puedan bibir en paz». ${ }^{8}$ La mencionada ley sintetizaba una parte esencial

6 Sobre el sentido que le da P. Bourdieu a este concepto, íntimamente emparentado con el maná de E. Durkheim y el carisma de M. Weber, cf. Bourdieu 1997: 172-173. P. Bourdieu reflexiona sobre el capital simbólico del rey, así como sobre la forma objetivada y codificada de éste, denominada capital jurídico, que fue siendo concentrado en la figura del monarca durante este período histórico, en Bourdieu 1993: 55-57.

7 Part 2,1,5. Más allá de esta norma, el vicariato divino del emperador se afirmaba en $\mathrm{P}$ (por Part) 2,1,1, mientras que el del rey se afirmaba de forma expresa en $P 2,13,26$ y con otras palabras en $P 2,1,7$, $2,2,4, \mathrm{P} 2,5,9$, P 2,13,1, P 2,13,6, P 2,13,13, P 2,13,14, P 2,13,15 y P $2,15,1$, emparentadas con C. Justiniano 1,1,8,pr. Sobre el origen divino del poder y sobre el vicariato divino del rey en las Partidas existe una vasta bibliografía en la actualidad, cuyos textos fundamentales irán siendo comentados a lo largo del presente estudio. En todo caso, para un estudio de estos temas en relación con la figura del rey en el ámbito europeo, desde sus primeras formulaciones hasta las más elaboradas de época tardomedieval, cf. Canning 1993; Ullmann 1985 y 1999. En cuanto a la equiparación jurídica del rey con el emperador en las Partidas a través de la figura del vicariato divino, cf. Maravall 1999a: 94-101 y Martin 2000. Pero no sólo los emperadores y los reyes eran nombrados como vicarios de Dios en las Partidas, sino que, dada su función en la espada espiritual, los obispos eran designados como vicarios de la divinidad en su obispado, según Part 1,5,3, así como el papa respecto de toda la Iglesia, cf. P 1,5,8 y P 2,1,1. Sobre este particular, cf. Panateri 2015b: 266-270.

8 Respecto de la caracterización del rey como cabeza de la comunidad, podemos encontrarla también en distintas normas de este código, como muestran las leyes Part 2,1,pr., P 2,9,6, P 2,10,2, P 2,13,6, $P 2,13,26, P 2,26,4, P 3,4,1$ y $P 2,1,5, P$ 2,1,7. Estas dos últimas normas, de influencia aristotélica, abordan, además, un tema clave de la arquitectura política de las Partidas, cual es el nacimiento del poder político del rey por una necesidad de orden natural, lo que también se observa, dentro de la legislación alfonsí, en el Espéculo, cf. Esp 2,1,3, y, fuera de ella, en el De Regimine Principum ad Regem Cypri de Tomás de Aquino, cf. De Regimine Principum 1,1 (cf. Maravall 1999a: 92-93 y Nanu 2013. Por otra parte, el rey, como corazón y alma de la comunidad, es caracterizado en P 2,1,5, P 2,10,2 y en P 2,13,26. Sobre esta concepción corporativa del reino en ámbito castellano, cf. Maravall 1999a: 89-136 y 1999b, I: 177-200. Posteriormente la cuestión ha sido abordada también en diversos trabajos, entre los que podemos citar a Nieto Soria 1988: 90-98 y Marey 2014: 235. Para un estudio de esta teoría corporativa fuera del ámbito castellano, cf. Chroust 1947; Kantorowicz 1985: 188-259; Canning 1980, 2008 y 1993: 172-173, entre otros trabajos que podrían citarse, particularmente de este último autor. Respecto de la afirmación de la elección divina del rey, ésta se encontraba expresa o tácitamente en diversos títulos de la Segunda Partida, como muestran las leyes Part 2,1,5, P 2,2,2, P 2,2,4, P 2,5,9, P 2,13,6, P 2,13,13, P $2,13,14$, $P 2,13,15, P 2,13,25, P 2,13,26$ y $P 2,15,1$, así como también se aprecia en el proemio de la Primera Partida. Además en las leyes I y II, del título XV, del libro II, se establecía que la primogenitura del futuro rey era decisión de la divinidad. Pero los reyes no sólo eran elegidos 
del ideario político del monarca, que legitimaba su figura y vehiculaba las relaciones jurídico-políticas con sus súbditos sobre elementos complementarios de tipo organicista y de naturaleza espiritual y, además, explicitaba la función inseparable a su vicariato, consistente en dar justicia a todos. ${ }^{9}$ Esta arquitectura intelectual, aquí brevemente enunciada en estas normas, contaba en Castilla con el precedente legislativo y de teoría política visigodo, ${ }^{10}$ con algunos antecedentes castellanos prealfonsinos ${ }^{11} y$, más directamente, seguía los paráme-

por Dios, sino también mantenidos por éste en su puesto (cf. P 2,1,6), lo que nos marca un carácter protector o ayudador de la divinidad respecto del rey que también encontramos en otros textos del scriptorium alfonsí. Concretamente, y bajo estos esquemas simbólicos, se narra en el Lapidario cómo Dios quiso que llegase a manos del infante Alfonso un libro escondido, que le transmitió vastos conocimientos que serían de utilidad para su posterior obra literaria (cf. Lapidario, pr.), mientras que, en el Libro de las Cruzes, se narra cómo Dios puso en Alfonso $\mathrm{X}$ mayor sabiduría que la que tenían los príncipes de su tiempo (cf. L. Cruzes, pr.). Por otra parte, respecto del rey Fernando, en el Setenario se desarrollaban las virtudes y las buenas costumbres que colocó Dios sobre él, cf. Set 5, S 6 y S 7 (en cuanto al fundamento espiritual de la autoridad política y la especial relación de la divinidad con Fernando III en el Setenario, cf. Martin 1995: 14-16). Pero también la Virgen había intervenido a favor del rey y de su familia en diferentes ocasiones, por ello en el proemio de las Partidas se establecía que la Virgen era medianera entre Dios y el rey. Además, en las Cantigas de Santa María podemos apreciar una enorme cantidad de piezas en las que la Virgen intervenía a favor de Alfonso $X$ y de su propia familia, lo que es muestra, en opinión de J. M. Nieto Soria (1997: 68-69), de la relación privilegiada que el rey tenía con la divinidad. Para un análisis con buen criterio de algunas de estas cantigas, cf. Kleine 2014a: 24-27. Más allá de estas razones de fondo, existía una cuestión semántica que vinculaba al rey con la divinidad en las Partidas, en la medida en que, según el código alfonsí, Cristo mismo era rey, y de ello habían de tomar los reyes su nombre, cf. Part pr., P 2,1,6, P 2,2,2 y P 2,13,1. Respecto de este particular, véanse también F. Real 1,5,4, Esp 2,1,5, Set. 89 y CSM 221, por lo que se trataba de una idea recurrente en la teoría política alfonsí.

9 La función de dar o hacer justicia como la principal del rey se repetía a lo largo del texto en distintas leyes bajo distintas enunciaciones, como muestran Part pr., P 1,4,13, P 2,1,5, P 2,1,6, P 2,1,7, P 2,2,4 P $2,5,9, P$ 2,5,12 y P 2,13,1. Ello ha de ser conectado, dado el carácter de vicario de Dios del propio rey, con la concepción de la justicia como medianera entre Dios y el mundo establecida por P 2,9,28. Por otra parte, esta concepción de la justicia como medianera entre lo sagrado y lo profano bebe de los espejos de príncipes de la época, a la luz de los cuales las normas de las Siete Partidas reciben una mejor interpretación. De esta manera, respecto de los espejos de origen oriental, en Bocados de Oro podemos leer que la justicia es «peso que puso Dios en la tierra, y con él toma su derecho el flaco del fuerte, y el verdadero del falso" (Bocados 14: f.27r.), mientras que en Poridad de las Poridades se establece que la justicia es de las maneras de Dios (cf. Poridad 3), y, en la literatura de espejos de creación castellana, hallamos que la justicia es silla de Dios (cf. 12Sabios 18). Respecto de la función de la justicia en la obra de Alfonso $\mathrm{X}$ conviene tener presente las obras de Ferrari 1934: 452-454; Nieto Soria 1986: 720-721; Macdonald 1987; Walmisley-Santiago 1993; Madero 1996; López 2003 e Iturrioz 1955: 17-20, por citar algunas de las principales obras sobre la materia.

10 En el Liber ludiciorum encontramos el origen divino del poder (cf. L. ludiciorum Pri. Tit. 9), así como la imagen corporativa del reino, por la que el rey era cabeza del mismo (cf. LI 2,1,4). En cambio, en esta normativa no se recogía la caracterización del monarca como vicario de Dios, como sí se aprecia en el canon IX del Concilio XVI de Toledo, tras una evolución que partía de la concepción del rey como mandado de Dios del canon único del Concilio III de Toledo y que se enriqueció con las aportaciones de Isidoro de Sevilla (para un estudio en detalle de la concepción de Isidoro de Sevilla sobre la realeza y de su asociación con la divinidad, cf. Grein 2010).

11 Cf. Ubieto Arteta 1991: 159-160, que ubica el origen de la fórmula de derecho divino de rey por la gracia de Dios en tiempos de tros fundamentales ya establecidos en la legislación alfonsí, muy particularmente en el Fuero Real y el Espéculo, que caracterizaban al rey en sus arquetipos de elegido por $\operatorname{Dios}^{12} y$ de corazón o alma del pueblo, ${ }^{13}$ y que establecían la función por la que Dios puso a los reyes sobre las gentes, cual era la de hacer justicia en su reino. ${ }^{14}$

Los elementos centrales de esta arquitectura ideológica, en cuanto a la concepción del rey y el origen divino de su poder, también se encontraban desarrollados en los espejos de príncipes castellanos de la época, lo que nos proporciona una información de utilidad sobre la difusión de estas ideas en el siglo XIII y sobre el sustrato teóricopolítico que sirvió de influencia en la redacción del código de las Partidas. ${ }^{15}$ Concretamente, El libro de los doze sabios establecía que el rey que usaba bien de la justicia era medianero de los hechos de Dios, ${ }^{16}$ en tanto que El libro de los cien capítulos era especialmente prolijo en este asunto, pues apreciamos en él la concepción del rey como elegido por $\operatorname{Dios}^{17}$, como representante suyo ${ }^{18}$ y como cabeza y alma del reino. ${ }^{19}$ Por su parte, en los espejos de origen

Fernando I. En las Partidas esta fórmula se convirtió en una exigencia legal para determinados documentos en las leyes VII, VIII y XIX, del título XVIII, del libro III.

12 Cf. F. Real 1,2, FR 1,5,4 y FR 4,21,5, Esp 1,1,13, E 2,1,pr. y E $2,1,6$. Posteriormente a las Partidas, en el Setenario, volvemos a hallar la designación divina del rey, cf. Set 1. Por otra parte, no como declaración original, sino como fórmula jurídica ritualizada, esta imagen también aparece en el proemio de muchas de las obras jurídicas de Alfonso $\mathrm{X}$, como en las Partidas, el Fuero Real, el Setenario, las Leyes Nuevas, el Ordenamiento de las Tafurerías, el Ordenamiento de las Cortes de Valladolid de 1258 y en el Ordenamiento de posturas y otros capítulos generales otorgados en el ayuntamiento de Jerez en 1269. Fuera de los textos legales, esta fórmula la hallamos en el proemio de otras tantas (cf. L. Acedrex, L. I. Estrellas, L. F. I. Cielos, P. C. General, G. Estoria, entre otras), pero, en lo que nos despierta aún mayor interés, la imagen del rey elegido por Dios también se encuentra en la literatura no jurídica del scriptorium alfonsí no ya como fórmula ritualizada de carácter introductorio, sino como parte misma del relato, añadiendo información a la biografía de algunos reyes, lo que se comprueba entre otros en G. Estoria 3,1: 327, G. Estoria 3,1: 437 y CSM 401.

13 Cf. F. Real 1,2 y Esp 2,1,1, E 2,1,4 y E 2,1,6.

14 Cf. F. Real 1,5,4 y Esp 2,1,5, sobre este particular véase también Set 89. Fuera de la literatura jurídica, cf. CSM 221.

15 Respecto de la influencia de los espejos de príncipes en la redacción del código alfonsí, particularmente en lo que se refiere a la configuración de la figura del rey y muy especialmente en cuanto a la colección sapiencial de Secreto de los Secretos, cf. Rucquoi y Bizzarri 2005. Un estudio más extenso sobre la influencia de los espejos de príncipes, no sólo castellanos, en la Segunda Partida es el de Nanu 2013.

\section{Cf. 12Sabios 18.}

17 Cf. 100Cap 1. En este mismo capítulo, y en la misma línea, se establecía que «el rey es fiel de Dios en su tierra e so fiel sobre aquel pueblo que l' metió en poder», mientras que en el capítulo III podemos leer que «el rey es fiel e alamín de Dios sobre su pueblo que l' metió en poder». El origen divino del poder del rey también se aprecia en este capítulo III, pues, refiriéndose a él, dice que «Dios le fizo mercet, e le dio el regno, e le metió en poder los cuerpos e los averes del pueblo».

18 Cf. 100Cap 3. Íntimamente relacionado con ello, en este texto también apreciamos la concepción del rey como senescal de Dios que tiene su poder en la tierra (cf. 100Cap 1) y como árbol de Dios que tiene gran sombra (cf. 100Cap 1. Acertadamente M. Haro Cortés entiende que también esta imagen remite a la concepción del rey como representante de la divinidad, cf. Haro Cortés (ed.) 1998: 74).

19 Como cabeza del resto, cf. 100Cap 1 y 3, mientras que como alma, cf. 100Cap 5. Respecto del carácter corporativo del reino en los espejos de príncipes de creación castellana de la época, cf. Haro Cortés 1996: 54-56. 
oriental hallamos la designación divina del rey en Calila e Dimna ${ }^{20}$ y en Secreto de los Secretos, ${ }^{21}$ y la figura del rey asociada a la del ánima del pueblo en Bocados de Oro, 22 de la misma forma que, como vemos, se encontraba en las leyes de Alfonso X. Pero estas colecciones no sólo sirvieron como fuente en materia de teoría política para la redacción de textos jurídicos, sino que su difusión formaba parte de la misma corriente propagandística emprendida por la monarquía ${ }^{23}$, la cual generaba una situación de violencia simbólica ${ }^{24}$ que se imponía no ya de un grupo social a otro, sino del rey sobre su pueblo, como podrá comprobarse en adelante. Fuera de la península, elementos esenciales de este entramado simbólico, levantado sobre argumentos complementarios tanto de naturaleza espiritual como relativos al carácter corporativo del reino, podemos encontrarlos desde la plena Edad Media en diferentes espejos de príncipes, pero fue el Policraticus, de Juan de Salisbury, su principal exponente, del que bebieron posteriores obras dedicadas a la educación de los futuros reyes en el occidente europeo. ${ }^{25}$

Por otra parte, dentro del código de las Partidas, la

\section{Cf. Calila 14: 469}

21 Cf. Secreto 8.

22 Cf. Bocados 1: f.5r. Además en Bocados de Oro encontramos a lo largo de su capítulo XV una interesante disputa entre el rey Darío y el rey Alejandro sobre la divinidad de ambos.

23 Sobre este tema, cf. Bizzarri 1995: 35-46.

24 Sobre el sentido que le da P. Bourdieu a este concepto podría citarse una gran pluralidad de obras, pero baste a estos efectos Bourdieu 1997: 172-173.

25 Bajo sus enunciados, el poder encuentra su origen en la divinidad y el príncipe es el mandado o representante de Dios, cf. Poli 3,15 y $\mathrm{P} 4,1$. Por otra parte, también hallamos en el Policraticus la imagen corporativa, por la que el príncipe es la cabeza de la comunidad política, pero, a diferencia de lo establecido en las Partidas, el rey en este constructo quedaba subordinado a la Iglesia, en los siguientes términos: "y se halla sujeto solamente a Dios y a quienes en nombre de él hacen sus veces en la tierra, como en el cuerpo humano la misma cabeza tiene vida y es gobernada por el alma» (Poli 5,2. Para una reflexión sobre ésta y otras diferencias entre las imágenes corporativas del Policraticus y de las Partidas, cf. Nieto Soria 2006: 22 y Nanu 2013: 61-64 y 86. Para un estudio más detenido de esta obra y de sus implicaciones en la teoría política medieval, cf. Liebeschütz 1950; Ullmann 1944 y Post 2006: 513-521). Por su relación con las Partidas, nos referiremos asimismo al De Regimine Principum ad Regem Cypri, de Tomás de Aquino, donde se recoge el origen divino del poder del rey (cf. De Regimine Principum 1,2, DRP 1,4 y DRP 1,5), a quien se considera como ministro de Dios y representación de la divinidad (cf. DRP 1,8 y DRP $1,9)$, así como el carácter corporativo de la sociedad, con el rey a modo de cabeza, corazón (cf. DRP 1,1) o alma (cf. DRP 1,12). Y, al igual que en el Policraticus, pero a diferencia de las Partidas, hallamos en este texto de Tomás de Aquino la necesaria subordinación de los reyes a los papas, que son los únicos expresamente nombrados como vicarios de Jesucristo (cf. DRP 1,14). Respecto de las influencias de las Partidas sobre el De Regimine Principum, cf. Martin 2000: 340-348. Una visión contraria es la sostenida, entre otros autores, por I. Nanu, para quien la relación circuló en sentido inverso, de manera que, según la autora, el De regimine Principum de Tomás de Aquino fue, junto con el De eruditione principum de Guillermo Peraldo, dentro de la literatura especular que recogía la tradición política del Policraticus, una de las fuentes más destacadas de las Partidas en materia de teoría política, cf. Nanu 2013. Pero ésta es una cuestión no carente de complicaciones, puesto que, de ser aceptada, tendríamos que retrasar la fecha de confección de la Segunda Partida, o al menos del códice o la versión que recogiera estas influencias, a una etapa más tardía del reinado de Alfonso $X$, como mínimo, según la propia autora, hasta la segunda parte del año 1274 (cf. ibíd.: 290). teoría política regia no sólo se recogía en la literalidad de las leyes en ella contenidas, sino también aparecía a modo de alegoría pictórica en distintas miniaturas que acompañaban a los textos en el códice más antiguo que se conserva de las Partidas, de 1290. Para comprender el papel de estas piezas en el proceso de fortalecimiento del capital simbólico del rey, analizaremos dos de ellas, de entre las diversas miniaturas que podríamos traer en este punto (ver figuras 1 y 2$).^{26}$

FIGURA 1

Alfonso X ordena escribir las Partidas, British Library, Add. ms. 20787: f.1v. Extraída de Bango Torviso, G. I. 2010-2011: 16

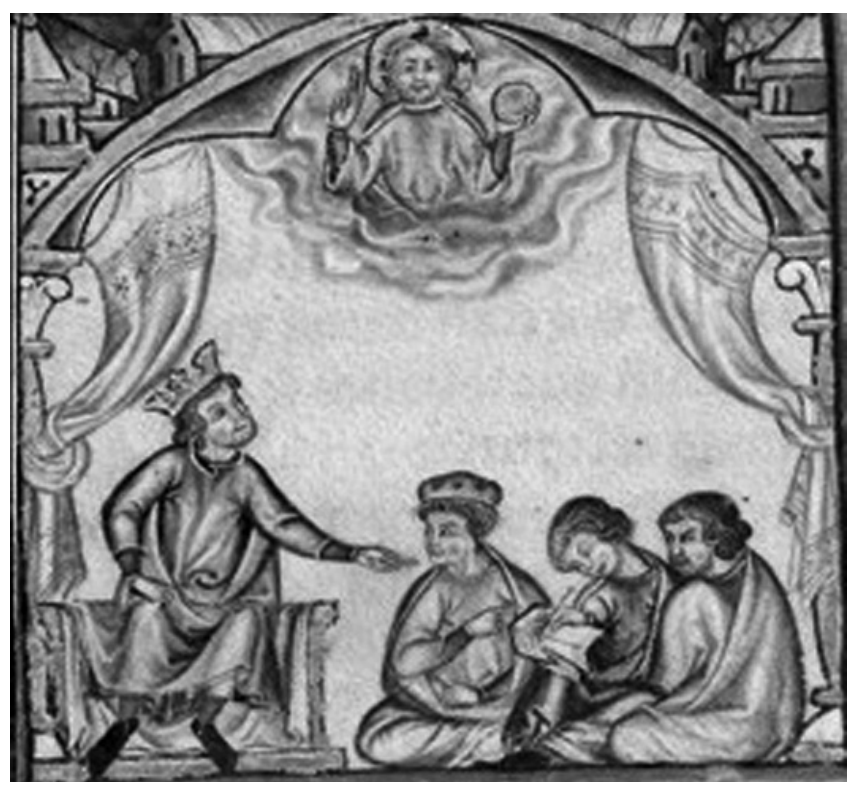

- En la miniatura de la figura 1 observamos un escenario cortesano, en el que el rey Alfonso $\mathrm{X}$ ordena a un escriba copiar las leyes que le va dictando, y que habrán de regir a la comunidad, y uno celestial, desde donde la divinidad contempla cómo se cumplen sus designios, en la medida en que su vicario lleva la justicia y la paz a la espada temporal. ${ }^{27}$ Sobre este carácter del rey como ser cargado de maná, al que obedecen los hombres, tendremos ocasión de referirnos en el apartado tercero de este trabajo, como también haremos respecto de los objetos de poder que separaban simbólicamente al rey de sus súbditos (trono y corona aparecen en esta miniatura) y respecto de la diferente altura a la que debían situarse los súbditos en presencia de su rey según las Partidas, lo que tiene también su traducción pictórica en esta pieza.

26 Para ver otras miniaturas de este códice de las Partidas que hacían alusión a la especial conexión del rey con la divinidad, cf. Domínguez 2008-2009 y Bango Torviso 2010-2011. Un repertorio más amplio de miniaturas de este códice lo encontramos en Arias Bonet (ed.) 1975.

27 También A. Domínguez (2008-2009: 244) e I. G. Bango Torviso (2010-2011: 16) interpretan la miniatura como una alegoría del vicariato divino del rey. 
FIGURA 2

Alfonso $X$ se arrodilla ante Dios, British Library, Add. ms. 20787: f. 1 r. Extraída de Bango Torviso, G. I. 2010-2011: 16

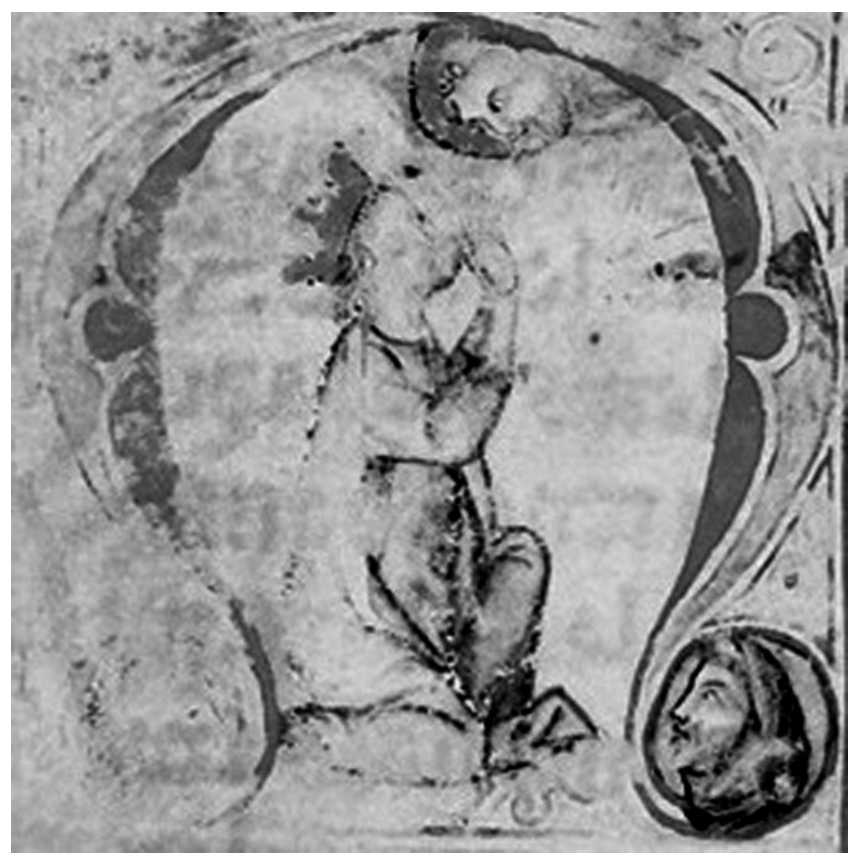

- La miniatura de la figura 2 también es una alegoría del vicariato divino del rey, no obstante, en ella el rey no habla con sus oficiales, sino que lo hace directamente con la divinidad, lo que, bajo una interpretación en clave durkheimiana, y sin olvidar el carácter alegórico de la pieza, sólo podría hacer de tener él mismo naturaleza sagrada en ese momento, como la tienen Dios, los ángeles y otros seres. ${ }^{28}$ Por lo tanto, en esta miniatura no apreciamos dos planos separados, sino que Alfonso $X$ se expresa con la divinidad sin intermediarios de ningún tipo, en un único escenario, en el que Dios se encuentra en la posición más elevada, como marca la cosmovisión cristiana y en particular la arquitectura teológica alfonsí. ${ }^{29}$

Afirmada en las Partidas la intermediación del rey y del emperador entre Dios y los hombres a través de la figura del vicariato divino, ${ }^{30}$ ya fuese en la literalidad de las leyes o en las miniaturas que las enriquecían visualmente, hemos de ampliar nuestro foco y distinguir otras figuras que desempeñaban un papel análogo de intermediación en el

28 Cf. Durkheim 1968: 43-44. Ana Domínguez describe la naturaleza de la miniatura y su pobre estado de conservación bajo la siguiente interpretación, haciendo hincapié en la representación del vicariato divino: «En esta ocasión el monarca está arrodillado y se dirige hacia lo alto en donde está representada la cabeza de Dios. Aunque esta miniatura está deteriorada, como si hubiera sido objeto de borraduras, por una censura de época posterior a su confección, la idea de que el monarca es el vicario de Dios en la tierra y el único fazedor de leyes en su reino se expresa claramente» (Domínguez 2008-2009: 242).

29 Conforme a ella, Dios residía en el lugar más alto del mundo, en el noveno cielo, más allá de los planetas y de las constelaciones, cf. Set 35.

30 Sobre la manifestación de lo sagrado a través de distintos seres, que necesariamente son revestidos de sacralidad en este proceso y convertidos en mediadores entre los dos planos del mundo, cf. Caillois 1984: 99 y Eliade 2010: 147-150. repertorio jurídico alfonsí, para ubicar en su contexto la actuación del poder político. Así vemos cómo, con distintas atribuciones, también correspondía o había correspondido este papel de médium entre ambos planos del mundo tanto a Cristo, ${ }^{31}$ como al Espíritu Santo, ${ }^{32}$ los ángeles, ${ }^{33}$ la Virgen María, ${ }^{34}$ los doce apóstoles, ${ }^{35}$ los santos, ${ }^{36}$ los profetas, ${ }^{37}$ Abraham, ${ }^{38}$ el papa, ${ }^{39}$ los obispos, ${ }^{40}$ el capellán del rey, ${ }^{41}$ los confesores ${ }^{42}$ y los clérigos en general. ${ }^{43}$ En consecuencia, la llave de la comunicación entre los dos planos del mundo era compartida, si bien sólo al emperador y al rey correspondía el gobierno de las cosas temporales en su territorio, mientras que los otros se ocupaban de intervenir en las espirituales, lo que ha de ser interpretado a la luz de la teoría recogida en el propio código alfonsí de las dos espadas, que explica la procedencia divina del poder terrenal. ${ }^{44}$

Por lo tanto, en las Partidas nos encontramos con una visión teocéntrica de la realidad y con una función determinante del monarca, como medianero entre los dos planos de la misma, lo que lo convertía en algo distinto a un simple hombre ${ }^{45} \mathrm{y}$ además generaba un haz de consecuencias lógicas que impregnaban este texto normativo. Particularmente, nos interesan los condicionamientos que implicaba este aparato ideológico en el actuar del rey y en el de sus súbditos, pues ello nos mostrará un ámbito de influencia que se desplegaba en ambas direcciones. Así, respecto del primero, el vicariato divino imponía un condicionamiento genérico al rey en el desempeño de sus funciones, ya que, siendo un representante de la divinidad, había de consti-

31 Cf. Part 1,4,58 y 2,12,7, entre otras, así como en innumerables normas del Setenario, entre las que destacamos Set 58, S 65, S 105 y S 107.

32 Cf. Set 37 y S 46.

33 Cf. Part 1,4,58, P 1,6,34 y Set 43.

34 Cf, Set 48 y S 60. Más allá de los textos jurídicos, respecto de las Cantigas de Santa María, para R. A. MacDonald si en las Partidas era el rey el principal medianero de Dios en la tierra, en estas cantigas era la Virgen la que jugaba este rol a través de su capacidad para hacer milagros (cf. Macdonald, 1987: 320). En cualquier caso, de acuerdo con la noción de milagro de las Partidas, la Virgen, como restauradora de la justicia, no sería más que un instrumento de Dios para intervenir en la tierra a favor del rey y de otros sujetos que lo merecieran: «Miraglo tanto quiere dezir, como obra de Dios marauillosa que es sobre natura vsada cada dia: e por ende acaesce pocas vezes, e para ser tenido por verdadero, ha menester que aya en el quatro cosas. La primera, que venga por el poder de Dios, e non por arte. La segunda, que el miraglo sea contra natura. Ca de otra guisa non se marauillarian los omes del. La tercera, que venga por merescimiento de sanctidad, e de bondad que aya en si aquel, por quien Dios lo faze. La quarta, que aquel miraglo, acaesca sobre cosa, que sea sobre confirmacion de la fe» (Part $1,4,68)$. Un estudio detallado sobre los distintos roles de la Virgen en estas cantigas es el de Pérez de Tudela 1992.

35 Cf. Set 41 y $\mathbf{S} 68$.

36 Cf. Part 1,23, pr. y P 2,4,4.

37 Cf. Set 53, S 103 y S 107.

38 Cf. Set 103.

39 Cf. Part $1,5,8$ y $P$ 2,1,1.

40 Cf. Part $1,5,3$ y $P 1,5,66$.

41 Cf. Part 2,9,4.

42 Cf. Set 100 y S 101.

43 Cf. Part 1,6,62.

44 Cf. Part 2, pr. y 2,1,1. Sobre este particular, cf. Maravall 1999a: 93-94; Nanu 2002 y Panateri 2015b.

45 En palabras de M. García-Pelayo: «El hombre en la Edad Media no siente que obedece a otro hombre, sino a aquel que, por estar dotado de chrisma de la realeza, es vicario de Dios ( )» (García-Pelayo 2009: 2455). 
tuirse en imago Dei y emplear el reino de Dios como modelo para gobernar el terrenal. ${ }^{46}$ Para esta empresa, el monarca habría de observar las obras de Dios y apoyarse en su fe, ${ }^{47}$ pero también disponía de un atributo asociado con frecuencia a la realeza por el scriptorium alfonsí, cual era la sabiduría, y que, acompañada de las anteriores, ayudaba al hombre a comprender la voluntad y los mandamientos divinos. ${ }^{48}$

Esta necesaria imitación de la divinidad se hallaba profundamente arraigada en la Segunda Partida y se ramificaba sobre diversos ámbitos, de entre los que destacaremos tres principales, que o bien ya hemos mencionado o bien habremos de analizar nuevamente, pues constituyen aspectos centrales del presente trabajo. En primer lugar, siguiendo

46 Para una reflexión genérica sobre este deber del vicario de Dios, cf. García-Pelayo 1959: 101-103. Con carácter más específico, respecto de Alfonso X y su legislación, cf. Nieto Soria 1988: 58-60 y Pérez de Tudela 1991: 185-187. El Fuero Real se expresaba muy claramente sobre este particular: «Nuestro señor Dios Jesucristo ordenó primeramientre la su corte en el cielo; et puso a sí cabeza e comenzamiento de los angeles e de los arcangeles; et quiso e mandó quel amasen e quel guardasen como a comenzamiento e guarda de todo. Et despues desto fizo el ome a la manera de su corte. Et como a sí avie puesto cabeza e comienzo, puso al ome la cabeza en somo del cuerpo, e en ella puso razón e entendimiento de cómo se devan guiar los miembros, e como deban servir e guardar la cabeza mas que a su mismos. Et desí ordenó la corte terrenal en aquella misma guisa, e en aquella manera que era ordenada la suya en el cielo, e puso el rey en su logar cabeza e comenzamiento de todo el pueblo, asi como puso a sí cabeza e comienzo de los angeles e de los arcangeles» (F. Real 1,2).

47 Cf. Part 2,2,1.

48 Cf. ídem. Por otra parte, de forma genérica leemos en la General Estoria que con la sabiduría reinan los reyes y señorean los príncipes (cf. G. Estoria 3,1: 390), pero, más específicamente, respecto de Alfonso X, en el Libro de las Cruzes se nos narra cómo Dios puso en él la sabiduría (cf. L.Cruzes, pr). En este sentido, para A. Rucquoi, los reyes castellanos poseían un carácter clerical, si no sacerdotal, en la medida en que todo saber provenía de Dios, bajo estas estructuras de significación, y que los reyes tenían una mayor sabiduría que e resto, cf. Rucquoi 1992: 71. Respecto de Dios como fuente del saber, cf. Part 2,5,16 y G. Estoria 3,1: 382. Dentro de los espejos de príncipes, que nos ayudan a comprender las tramas de significación insertas en este discurso propagandístico, también apreciamos la vinculación entre la sabiduría y la persona del rey, no en vano en Calila e Dimna se afirma que Dios otorga al rey seso, acuerdo y saber (cf. Calila 14: 469. Sobre la sabiduría y el rey, véase también Calila 2: 250), mientras que en Bocados de Oro se afirma que el rey es quien mejor piensa del pueblo (cf. Bocados 15: f.29v.). Respecto de la utilidad que reportaba la sabiduría, en la literatura sapiencial de origen oriental vemos cómo ésta era «huerta en que se depuertan las almas, y es segurança de los medrosos y solaz de los desconpañados, y esta es buena mercadura de las que della an sabor y este es la gracia y el bien y el entendimiento deste mundo y de aquel otro» (L. B. Proverbios 5). Todavía con una mayor claridad, en Bocados de oro se establecía que por el seso los hombres no sólo hacen justicia, sino que además se apartan del pecado (cf. Bocados 2: f.6v.) y que quien ama al seso y a las buenas obras recibe el amor y el cuidado de Dios (cf. Bocados 14: f.28v.). Expresiones semejantes encontramos en D.C.Sabios p.33 y 34 Sabios 23. Bajo parecidos esquemas ideológicos, en los textos del scriptorium alfonsí, en la General Estoria primero se describe a la sabiduría como un medio para ganar noble corona de vida en el otro sieglo (G. Estoria 3,1: 385), lo que posteriormente queda reafirmado, pues por la sapiencia se halla salut del Señor (G. Estoria 3,1: 390) y ella es guía de la virtud de Dios (cf. G. Estoria 3,1: 435). Respecto de las Partidas, en la ley $\mathrm{VI}$, del título XX, del libro II, se aprecia cómo la sabiduría era un medio para entender la voluntad de Dios, mientras que en la ley I, del título XII, del mismo libro, de declarada influencia aristotélica, se establecía que el alma razonable era un medio para «conocer a Dios, amarlo y temerlo». el modelo de unidad del reino celestial, esta construcción ideológica había de llevar al rey a preservar la unidad de su reino, siguiendo el arquetipo del reino celestial, como se aprecia en la ley V, del título I, del libro II:

E bien otrosi como el coraçon en vno, e por el resciben todos los otros miembros vnidad, para ser vn cuerpo, bien assi todos los del reyno maguer sean muchos (porque el Rey es e deue ser vno) por esso deuen otrosi ser todos vnos con el, para seruirle, e ayudarle, en las cosas, que el ha de fazer. ${ }^{49}$

Por otra parte, en cuanto a sus súbditos, el monarca tenía atribuido una serie de deberes que le conferían un rol salvífico, como el de que sus leyes procurasen la ganancia en el otro mundo de los hombres ${ }^{50}$, así como el de darles escarmiento por el mal así como recompensa por el bien, ${ }^{51}$ en aplicación de la justicia. ${ }^{52}$ Sobre este último particular, la Segunda Partida convertía al monarca en un distribuidor de dones sobre sus súbditos, ${ }^{53}$ lo que no sólo tenía implicaciones políticas y económicas, sino que también merece un análisis a la luz de la fenomenología de la religión, como una expresión del poder sagrado que vuelca sus dones sobre quienes se ejerce. ${ }^{54}$ Ciertamente el rol salvífico del vicario de Dios ha sido resaltado por la historiografía, ${ }^{55}$ pero se trata de un concepto que encuentra una interpretación más rica desde los estudios del fenómeno religioso, lo que ha sido realizado con solvencia por $\mathrm{G}$. van der Leeuw, quien analiza diversos casos históricos de reyes salvíficos. ${ }^{56}$

Finalmente, y en cuanto a sí mismo, el rey había de ser una figura virtuosa, apartada del vicio y del pecado, ${ }^{57}$ como establecían los espejos de príncipes de la época. ${ }^{58}$ No obstante, el rey no sólo había de comportarse de forma virtuosa por la necesidad de imitar a Dios, sino también porque era concebido como un espejo para sus súbditos, ${ }^{59}$ como lo son los reyes sagrados, por cuanto se proyecta sobre ellos un ideal moral para los hombres. ${ }^{60}$ Concretamente, en la ley IV, del título V, de la Segunda Partida se establecía

49 Véase también Part 2,9,1. Sobre la necesaria unidad del reino en la legislación alfonsí, bajo el modelo de unidad del reino celestial, cf. Iturrioz 1955: 80 y 94 y Nieto Soria 1988: 59-60.

50 Cf. Part $1,1,10$ y póngase en relación con $\mathrm{P} 1,1,3$ y $\mathrm{P} 1,1,6$, sobre la salvación de las almas.

51 Cf. Part 1,1,3 y P 2,28,pr. Respecto del galardón y el castigo, compárense estas normas con F. Real 1,2 y FR 1,5,1 y con lo dispuesto posteriormente en Set 106 . Por otra parte, este rol salvífico del monarca comprende, asimismo, el carácter ejemplar del rey, que desarrollamos en las páginas 13 y 14.

52 Cf. nota 9.

53 Cf. Part 2,5,18.

54 Para un análisis de la figura del rey sagrado distribuidor de dones, cf. Leeuw 1964: 107-108.

55 Cf. Ullmann 1985: 130.

56 Cf. Leeuw 1964: 113-121.

57 El ideal virtuoso de actuación del rey era desarrollado minuciosamente en el título $\mathrm{V}$ de la Segunda Partida, con mayor detalle respecto a lo dispuesto previamente en Esp 1,1,4. Sobre el debido comportamiento e incluso la apariencia del rey como vicario de Cristo en las Partidas, cf. Iturrioz 1955: 66-73; Pérez de Tudela 1991: 186-187; Nieto Soria 1997: 61-65 y Kleine 2014a: 35-39, entre otros.

58 Con acierto, J. M. Nieto Soria vincula las innumerables máximas de los espejos de príncipes de la época sobre la necesidad de que el rey fuese virtuoso con el discurso propagandístico de Alfonso X de afianzamiento de la figura regia, cf. Nieto Soria 1986: 719-720.

59 Sobre este tema, cf. Ferrari 1934: 451 y Kleine 2014a: 35-39.

60 Esta es una concepción durkheimiana de lo sagrado que podemos observar recurrentemente en Durkheim 1968. 
que «los reyes son espejos para sus súbditos, por ello deben de guardarse de obrar correctamente», ${ }^{61}$ lo que implicaba que un rey que no lo hiciera difícilmente podía reinar sobre un pueblo virtuoso. Más allá de las Partidas, esta misma idea podemos apreciarla en la Primera Crónica General, que, luego de afirmar que «todos los omnes del mundo se forman et se assemeian a manera de su rey", ${ }^{62}$ aseguraba que los pecados de diferentes reyes godos fueron también cometidos por sus súbditos, ${ }^{63}$ así como en el capítulo XIV de Bocados de oro, donde se advertía al rey de que no podría enderezar al pueblo, no siendo él enderezado. ${ }^{64}$

Como concreción de la necesaria imitación de Dios, en lo que a la actividad legislativa se refiere, el vicariato divino implicaba que las leyes del rey habían de beber del derecho de Dios en última instancia. ${ }^{65}$ Esta obligación respecto del derecho divino se aprecia bajo la siguiente fórmula alegórica en la Primera Partida: «El fazedor de las leyes debe de amar a Dios e tenerle ante sus ojos, quando las fiziere, porque sean derechas e complidas ${ }^{66}{ }^{6}$ que repite textualmente la fórmula de la ley IV, del título I, del libro I del Espéculo, que, a su vez, la recuperaba con algunas modificaciones del Fuero Juzgo, ${ }^{67}$ y que se complementa con la afirmación de

61 Sobre este particular, véase también Part 2,5,6, que exhortaba al rey a dar buenos ejemplos de sí mismo al pueblo.

62 P. C. General 559.

63 Cf. ídem. Respecto de este relato de la Primera Crónica General y de la semejanza de los yerros del rey a los yerros de su rey, cf. Kleine 2014a: 38-39.

64 Bocados 14: f.26v. Con otras palabras pero bajo el mismo esquema simbólico, en esta colección se afirmaba que «el rey es como el grande rio que nascen del grandes rios e pequeños: e si el es dulce todos son dulces: si el es salobre todos son salobres» (Bocados 12: f.22r.). En la literatura sapiencial europea, podemos apreciar también esta idea en el Policraticus (cf. Poli 6,29), así como en el De Regimine Principum ad Regem Cypri (cf. De Regimine Principum 1,3). Por otra parte, respecto de las consecuencias para el pueblo de no tener un rey sabio, cf. De Eruditione Principum 1,2.

65 Sobre la obligación de que la legislación del rey, entendido como vicario de Dios, fuese respetuosa con el derecho divino, cf. Bermejo Cabrero 1975; Nieto Soria 1988: 157; Haro Cortés 1996: 36 y Kleine 2014: 74. En todo caso, el establecimiento del derecho divino como fuente de las Partidas era algo que ya tenía muy claro el propio glosador Gregorio López, del que recogemos el siguiente comentario: "Hic dicit ex quibus fuerunt sumptae leges istae, a iure scilicet divino et naturali et ex dictis sapientum, et a iure communi et a bonis foris» (cf. López, G. (ed.) 1576. Las Siete Partidas del Sabio Rey don Alonso el nono nueuamente glosadas por el licenciado Gregorio López, glosa E tomemos a Part, pr. Salamanca: casa de Domingo de Portonarijs Vrsino). Por otra parte, desde el punto de vista teológico, siguiendo la narración de la ley XXXV del Setenario, la ley divina se hallaba en el noveno cielo, en el lugar donde moraba Dios, y de allí la había tomado Cristo para aplicarla en la tierra. En consecuencia, el papel del rey en las Partidas había de ser el mismo que el desempeñado por Cristo en el Setenario, cual era el de llevar la ley de Dios al reino de los hombres.

66 Part 1,1,11. Esta afirmación de las Partidas, que condiciona la actuación del legislador, bien podría tener una entidad independiente, pero las leyes han de ser interpretadas en su contexto normativo y ello nos obliga a analizar esta norma a la luz de la mencionada ley $\mathrm{V}$, del título I de la Segunda Partida, lo que nos lleva a comprender una parte esencial de la teoría política sobre la que se sustentaba este entramado jurídico.

${ }_{67}$ Cf. F. Juzgo 1,1,4. Más allá del ámbito peninsular, en el Policraticus de Juan de Salisbury encontramos una expresión muy semejante, en la medida en que se establecía que el príncipe «debe tener la ley de Dios ante su pensamiento y su mirada» (Poli 4,6), alegoría que se concretaba en ese mismo apartado en la exhortación al príncipe de no ignorar la ley de Dios. las Partidas en virtud de la cual las leyes de los hombres no deben ir contra la ley de Dios, ${ }^{68}$ entre otras normas que contribuían a sustentar esta construcción simbólica. ${ }^{69}$ La asociación de la ley de Dios con la de los hombres tenía que ser radical según las Partidas, puesto que en ellas se afirmaba el principio general de que toda ley, para ser considerada tal, debía contener unos mandamientos que fueran «leales, e derechos, e complidos segun Dios, e segun justicia», ${ }^{70}$ aunque no se llegaba a establecer expresamente, como sí harían las Leyes del Estilo con posterioridad, la ausencia de obligatoriedad de las leyes contrarias al derecho natural. ${ }^{71}$

En cuanto a la finalidad de las leyes, no debe extrañarnos, por lo tanto, que la primera norma de las Partidas dispusiera que «estas leyes son establescimientos, porque los omes sepan biuir bien, e ordenadamente, segun el plazer de Dios: e otrosi segund conuiene a la buena vida de este mundo, e a guardar la fe de nuestro Señor lesu Christo cumplidamente, assi como ella es». ${ }^{72}$ En consecuencia, era un objetivo de esta legislación que la misma sirviese para el cumplimiento del plan divino de salvación en la tierra, ${ }^{73}$ y esto se hacía constar antes que cualquier otra consideración, en la primera ley del código alfonsí. Por otra

\section{Cf. Part 1,1,18.}

69 Cf. Part 1,pr, P 1,1,4, P 1,1,6, P 1,1,9, P 1,1,16, P 1,1,17, P 1,2,5, $P 1,2,9$ y $P 2,2,4$, que encuentran un antecedente evidente dentro de la normativa jurídica alfonsí en $\mathrm{F}$. Real 1,6,1, así como en Esp 1,1,5, E $1,1,6$ y $\mathrm{E} 1,1,11$, y, fuera de ella, en F. Juzgo 1,1,2, FJ 1,1,4, FJ 1,1,5 y FJ $1,2,2$. Un estudio que aborda algunas de las leyes aquí mencionadas del código alfonsí, así como, con carácter general, la teoría de la ley en las Partidas, particularmente lo establecido en el título I, del libro I, es el de Panateri 2015a. En todo caso, la necesidad de la conexión entre la ley de Dios y la del rey no era contemplada exclusivamente por la legislación alfonsí, sino que también se encontraba en los espejos de príncipes de la época, como comprobamos en El libro de los doze sabios, donde se establecía que la voluntad del rey era amuchiguar la ley de Dios (cf. 12Sabios 26) y, dentro de los espejos de origen oriental, en Secreto de los secretos, que disponía que aquel rey que pusiera la ley divina sobre sus súbditos, digno era de reinar y de enseñorear (cf. Secreto 5). Fuera del ámbito peninsular, en el De regimine Principum ad Regem Cypri hallamos la conveniencia de que el rey estuviese instruido en la ley divina para lograr el fin de que la sociedad alcanzase la Bienaventuranza, cf. De Regimine Principum 1,15. Por otra parte, esta vinculación de la ley divina con la legislación de los hombres justificaba la repetida mención que hacía el legislador de las Partidas a los textos bíblicos como fuente de autoridad, como comprobaremos concretamente al analizar la ley XIV, del título XIII, de la Segunda Partida, entre otras muchas sobre las que podríamos detenernos.

70 Part 1,1,4.

71 Cf. L.Estilo 238.

72 Part 1,1,1. Esta ley fue analizada por A. Marey en la misma línea presentada en este estudio, bajo la premisa de que las leyes del rey habían de ordenar el reino terrenal de acuerdo con el orden divino, cf. Marey 2014: 232. De forma alegórica, esta obligación era recogida por la miniatura que encabezaba el título I, de la Primera Partida, del mencionado códice del British Museum, que retrataba a Alfonso X en actitud de sumisión, mostrando a la divinidad estas leyes a la espera de su aprobación (cf. Domínguez 2008-2009: 247). La finalidad de la ley prevista en las Partidas no era muy diferente a la prevista en el Fuero Juzgo. En concreto, en este texto se establecía que el legislador debía hacer la ley para que fuera asalvamiento del pueblo (cf. F. Juzgo 1,1,2), además se disponía que la ley es «por demostrar la cosas de Dios» (FJ $1,2,2)$.

73 Sobre la ley y otros vehículos de transmisión del saber, ya fueran el arte o incluso la historia, entendidos como estructuras culturales que orientaban, bajo este contexto simbólico del siglo XIII, al cumplimiento del plan divino y, por lo tanto, a la salvación de los hombres, cf. Ruíz Gómez 2008: 241-242. 
parte, dado que las leyes habían de reproducir el derecho divino, resulta comprensible que el llamado derecho público o comunal tuviese la consideración de sagrado por parte del legislador. ${ }^{74}$ No obstante, si abandonamos la perspectiva emic ${ }^{75}$ bajo un análisis desde la sociología de las religiones, no podemos obviar que el carácter sagrado de este derecho únicamente encontraría su justificación en la medida en que recogiese ideas o creencias compartidas por el pueblo o que consiguiese imponerlas. ${ }^{76}$

Finalmente, y como bien señala J. M. Nieto Soria, la teoría corporativa de las Partidas, construida en clave teológica en este entramado, justificaba que el rey mantuviera bajo control todos los miembros del cuerpo del que él era su cabeza, lo que se traducía en una mayor intervención legislativa en los distintos aspectos de las relaciones humanas, incluso en asuntos de la Iglesia, ${ }^{77}$ como se hace palpable en la normativa de la Primera Partida.

En todo caso, lo cierto es que era en el derecho penal de las Partidas donde esta construcción ideológica adquiría una intensidad particular. No por casualidad, en primer lugar, se equiparaba al pecado con el delito en el libro VII, en el que podemos leer que los delitos recogidos eran aquellos hechos realizados "contra los mandamientos de dios, e contra buenas costumbres, e contra los establescimientos de las leyes e de los fueros, e derechos $" .{ }^{78}$ Como correlato de lo anterior, la mención como pecados de los distintos tipos delictivos era usual, ${ }^{79}$ lo que, por el contrario, no resultaba frecuente en el entramado jurídico previo a Alfonso $X$, más allá del Fuero Juzgo. ${ }^{80}$ Bajo la influencia eclesiástica, en las Partidas se penaron también hechos que sólo tenían a Dios, a la Virgen o a los santos como sujetos directamente ofendidos, $^{81}$ a diferencia de lo que ocurría en el derecho

74 Cf. Part 1,18,2 (versión del códice del British Museum). Esta interpretación que justifica el carácter sagrado de la llamada ley pública o comunal en base a la necesidad de que la ley secular reprodujera la divina fue previamente realizada en Iturrioz 1955: 21-26, que además contiene un análisis de la teoría de la ley en las Partidas bajo el prisma teológico. Sobre este particular, véase también Nieto Soria 1997: 79-80.

75 Para comprender la significación de los enfoques emic y etic en antropología y sociología, cf. Harris 1976.

76 Respecto de la identificación de lo sagrado con la creencias compartidas por una sociedad, cf. Durkheim 1968: 224. Este autor considera que el derecho sólo excepcionalmente contradice las creencias sociales (cf. Durkheim 1995: 76-77). Por el contrario, D. Garland no considera excepcional que ello ocurra y confronta el análisis durkheimiano desde la sociología del poder, en el entendido de que las leyes, precisamente, pueden tratar de modificar ideas asentadas en beneficio de algún actor político, cf. Garland 2006: 73-74.

77 Cf. Nieto Soria 1989: 467.

78 Part 7,pr.

79 Cf. Part 7,4,4, P 7,14,21, P 7,17,4, P 7,18,pr., P 7,18,1, P 7,18,2, P 7,18,3, P 7,19,pr., 7,19,2, P 7,21,pr. P 7,21,1 P 7,21,2 y P 7,22,pr.

${ }^{80}$ La asociación entre pecado y delito era ciertamente infrecuente en el derecho foral castellano-leonés, salvo en la redacción del delito del acto homosexual, como puede comprobarse en el derecho de la familia de fueros de Cuenca-Teruel, cf. F. Cuenca $332(12,28)$, C. Valentino 2,2,22, F. Iznatoraf 304, F. Andújar 280, F. Alcaraz 4,81, F. Alarcón 285, F. Zorita 301, F. Béjar 386, F. Baeza 303, F. Plasencia 108, F. Sabiote 305, F. Huete 253 y F. Consuegra 279.

81 Dentro de la Séptima Partida tales son los casos del delito de tornarse judío o moro siendo cristiano, cf. Part 7,24,7 y 7,25,4, del delito de herejía, cf. P 7,26, y del delito de denostar a Dios, a la Virgen o a los santos, cf. P 7,27, por citar algunos ejemplos. castellano-leonés altomedieval. ${ }^{82}$ En cuanto a la naturaleza de las penas, en las Partidas se redujo considerablemente el ámbito de la venganza privada respecto de la legislación previa, ya que este tipo de acciones eran rechazadas por $\operatorname{Dios}^{83}$ y consecuentemente constituían un cuerpo extraño dentro del código normativo del rey. ${ }^{84}$ Además, el legislador configuró la pena, en el plano social, como medio para evitar el mal y enderezar al reino, ${ }^{85}$ lo que encaja con las obligaciones propias del vicario de Dios, mientras que, en el plano individual, apreciamos algunas normas que conceptuaban la pena como un instrumento para la enmienda e incluso para el arrepentimiento del individuo ${ }^{86}$. Por último, en aplicación expresa de la misericordia cristiana, el rey podía apiadarse de los súbditos y perdonar sus penas. ${ }^{87}$

En segundo lugar, esta imagen del vicariato divino implicaba una obligación esencial para los súbditos del rey, que habían de cumplir fielmente sus mandatos y no rebelarse a su autoridad, ${ }^{88}$ como disponían otros textos jurídicos del repertorio alfonsí, ${ }^{89}$ diversas leyes de las Partidas, donde se configuraba esta obligación en clave teológica, y los espejos de príncipes castellanos de la época, tantos los de origen oriental como los de creación castellana. ${ }^{90} \mathrm{El}$ rey descrito

82 Respecto de esta noción privada del delito, vinculada fundamentalmente al daño que un individuo infringía en otro, anterior a las Partidas y característica del derecho germánico, cf. Orlandis 1947: 68-69 y Foucault 1995: 76-77.

${ }^{83}$ Respecto de esta cuestión y de la influencia de la opinión de la Iglesia, así como del derecho romano, en la reducción de estos espacios de venganza privada en el derecho castellano, cf. López-Amo 1956: 339-342.

84 En este sentido, A. Morín analiza el caso problemático de la venganza privada, considerada como un pecado por la Iglesia, pero recogida como un derecho por la legislación del rey en el caso de la ley XIII, del título XVII, del libro VII, cf. Morín 2009: 121-134.

85 Cf. Part 1,1,3.

86 En cuanto a la pena como instrumento para la enmienda del individuo, cf. Part $1,4,63$ y $P 7,1,10$. Respecto de la pena como una vía para el arrepentimiento, cf. P 7,26,2 y P 7,17,15. En relación con esto, conviene traer a colación la máxima de Bocados de Oro, según la cual se aconseja al rey a no ser vengativo dando penas, sino a mostrar que trata de enderezar al súbdito, cf. Bocados 14: f.28r.

Sobre la influencia de la Iglesia en la concepción de la pena como un vehículo para la enmienda del individuo en el derecho bajomedieval, cf. López-Amo 1956: 351. Para un estudio más específico de las Partidas, cf. Serra Ruíz 1962-1963.

87 Cf. Part 2,10,2.

88 Cf. Ferrari 1934: 451; García-Pelayo 1959: 102; Nieto Soria 1986: 716-717 y 1997: 59.

89 Cf. F. Real 1,2 y 1,4 .

90 Respecto de la necesaria obediencia de los súbditos, ésta era recogida en las Partidas en diferentes normas, cf. Part 2,1,5, P 2,13,16, $P 2,13,26$ y $P$ 2,13,15 (en esta ley quedaba configurada en clave teológica, lo que no era una novedad del derecho alfonsí en nuestro derecho histórico, como puede comprobarse en L. Iudiciorum PT 9), y además se establecía no sólo el correlato necesario de la prohibición del regicidio (cf. P 2,13,26), sino también la pena de muerte para los que afirmasen querer su fallecimiento (cf. P 2,13,1), para los que codiciaren oír lo que le pudiese causar daño, muerte o deshonra (cf. P 2,13,2), para los que "sabor ouiessen» del daño y deshonra del rey (cf. P 2,13,3), así como para los que lo difamaren (cf. P 2,13,4). Ciertamente las Partidas admitían la posibilidad de que el rey se convirtiera en tirano (cf. P 2,1,10), pero no otorgaban el derecho de rebelión a los súbditos, aunque se advertía al rey de la posibilidad de perder el amor de los hombres por una mala actuación por su parte (cf. P 2,1,3, en esta ley sólo se menciona al emperador pero entendemos que es aplicable al rey por analogía, y P 2,5,10). En opinión de J. M. Nieto Soria, 
en las Partidas era una figura con enormes atribuciones de hecho y de derecho, que los súbditos habían de obedecer en todo momento y contra los que legítimamente podía reaccionar con brutalidad ${ }^{91}$. $Y$ esto nos habla de un rey cargado de maná, cuyos perfiles se definen adecuadamente desde un análisis que se adentre en la fenomenología de la religión ${ }^{92}$. Íntimamente relacionado, pero bajo esquemas weberianos, esta obediencia incondicional al rey constituye el tipo de obediencia característica de un sistema de dominación carismática. ${ }^{93}$

Además, según las Partidas, los súbditos no sólo debían obedecer al monarca, sino que, entre otras obligaciones configuradas en este código, habían de sentir hacia él tanto amor como temor, ${ }^{94}$ lo que situaba su relación en un

que compartimos, esta ausencia de reconocimiento del derecho de rebelión en las Partidas se explica en el marco de reforzamiento de la autoridad regia en el que se ubica este proyecto jurídico, cf. Nieto Soria 2005: 75. En todo caso, si bien los súbditos habían de obedecerlo en todo momento, pese a que el rey se separase del plan divino en su actuación, éste habría de rendir cuentas ante Dios, quien lo castigaría en esta vida y en la siguiente, con lo cual la actuación injusta o desmesurada del rey terminaría siendo fiscalizada, como se comprueba reiteradamente en la literatura jurídica, cf. Part 1,pr, P 2,2,2, P 2,2,3, P 2,2,4, P 2,3,4, P 2,3,5, P 2,4,2, P 2,4,3, P 2,4,4, P 2,5,2, P 2,5,3, P 2,5,4, P 2,5,7, $P 2,5,10, P 2,5,11, P 2,5,12, P 2,5,20$ y P 2,10,2, y en Secreto 1, S 2, S 11 y también en 100 Cap 3 , entre otras máximas que podríamos citar de la literatura castellana de espejos de príncipes. Pero es en la narración de un acontecimiento particular en Secreto de los secretos en el que hallamos una de las formas concretas en la que la divinidad podía castigar a los tiranos en este mundo, pues, según su capítulo II, Dios mandó a los tiranos del reino de Inguala un viento destructivo para dañarlos, luego de lo cual, el pueblo, que había implorado el auxilio divino, pudo destruirlos y eliminar sus nombres de la tierra. Ciertamente se trata de un caso digno de mención, pues, si bien no reconocía expresamente el derecho a la rebelión contra el rey devenido en tirano, sí sentaba un precedente muy significativo, que había de servir a los reyes para medir sus acciones. Fuera del ámbito peninsular, el De regimine Principum ad Regem Cypri, a diferencia del Policraticus (cf. Poli 3,15), no reconocía el derecho de rebelión frente al tirano por parte del pueblo, salvo que a éste hubiera correspondido el derecho a elegirlo, pero advertía al tirano del castigo con el que Dios podía librar al pueblo de aquel gobierno (cf. De Regimine Principum 1,5 y DRP 1,6). Por otra parte, conviene que abandonemos los textos jurídicos del scriptorium alfonsí y los espejos de príncipes, para adentrarnos en El libro del acedrex, que nos proporciona información valiosa respecto de cada una de las piezas del tablero, particularmente de la figura del rey, sobre e que recogía una serie de máximas que transcendían la mera explicación técnico-táctica del juego. Así, en uno de los capítulos en los que se explicaban los movimientos de esta pieza, el texto se adentraba en cuestiones de teoría política al reconocer que, aunque los súbditos no podían prender al rey o herirlo o matarlo bajo ninguna circunstancia, sí podían realizar diferentes acciones en contra de su voluntad en situaciones límite. Ello, verdaderamente, suponía el reconocimiento de un espacio de autodefensa frente a la arbitrariedad regia no reconocido en la literatura jurídica de Alfonso $\mathrm{X}$, en los siguientes términos: «Ca el rey es acotado en guisa que puede tomar a todos e ninguno non puede tomar a él, e esto es semejança del rey que puede fazer justicia en todos los que la merecieren, más por esso non debe poner la mano ninguno en él pora prenderle, nin ferirle nin matarle, aunque él fiera o prenda o mate, mas bien le pueden fazer vergüenza en tres maneras: faziendol salir de la casa don está, o embargandol la casa ó quiere entrar, e nol dexar tomar lo que quiere» (L. Axedrez 4).

91 Cf. Part 2,13,6.

92 Sobre el maná del rey sagrado y la figura de éste analizada desde la fenomenología de la religión, cf. Leeuw 1964: 105-121.

93 Sobre la obediencia debida bajo el tipo de dominación carismática, cf. Weber 1964: 170-241. Por otra parte, para la influyente reinterpretación de E. Shils del carisma de M. Weber, cf. nota 162.

${ }_{94}$ Cf. Part 2,12,pr., P 2,13,14 y P 2,13,15. plano emocional, ${ }^{95}$ como también hacían los espejos de príncipes de la época ${ }^{96}$. Ello constituye otro de los rasgos de la dominación carismática ${ }^{97}$ y ha de ser conectado con la impresión que generan las cosas sagradas en el hombre ${ }^{98}$. En lo que resulta de indudable interés a estos efectos, las Partidas se servían de la autoridad bíblica para dotar de un fundamento religioso a la relación sentimental que los súbditos debían a su rey, al recordar que:

(...) ningun ome non podria amar a dios complidamente, si non amasse a su Rey. E esto mesmo predico el Apostol sant Pablo, diziendo al pueblo que amassen a los reyes con todos sus coraçones, ca ellos eran puestos para castigarlos e aconsejarlos. Onde los que asi non lo fiziessen, non amarian derechamente a Dios nin a su Señor natural. E sin la vengança que tomaria dellos Dios en el otro siglo, non les deue el Rey amar en este: mas darles pena segund fuere el yerro del desamor, quel mostraren. ${ }^{99}$

En nuestra opinión, la configuración de estas obligaciones en clave teológica y el recurso a la Biblia como fuente de autoridad no deben ser tratadas como cuestiones menores, sino al contrario, dada la significación de la religión como entramado simbólico con el que los hombres filtran la experiencia e interpretan el mundo, particularmente en las sociedades tradicionales, como se han encargado de estudiar antropólogos y sociólogos. ${ }^{100}$ Ello justifica que dediquemos una especial atención a estas cuestiones en el presente trabajo.

\subsection{Las necesidades de operatividad política del rey}

El discurso que convertía al rey en un vicario de Dios, sometido a un ideal moral, estaba construido de tal manera que generaba espacios no reducidos de maniobrabilidad política. En primer lugar, y conforme a la urdimbre de significaciones de las Partidas, la ira, la saña y la malquerencia del rey quedaban justificadas en determinados casos, puesto que la propia divinidad, que había de imitar, manifestaba su ira y su saña en este mundo, ante los hombres y ante el rey si no se

95 Respecto de esta relación con el rey, que las Partidas trasladaban al ámbito emocional a través de los polos antagónicos amortemor, que vehiculaban la relación con el poder regio en la época, cf. Foronda 2013. Sobre el amor y el temor al rey en las Partidas, véase también Iturrioz 1955: 69.

96 En cuanto al amor al rey, en Flores de la filosofía se encuentra la siguiente máxima que lo consagra bajo esquemas teológicos: «E sabed que quien ama a Dios ama a sus cosas, e quien ama a sus cosas ama a la ley, e quien ama a la ley deue amar al rrey que la mantiene», cf. Flores 1,10 . Numerosas son las máximas sobre el amor y temor al rey en estos textos, pero particularmente interesante resulta la mención en el capítulo XXVI de Bocados de oro, conforme a la cual estos sentimientos conforman el contenido de la obediencia al monarca: «Obedecer al rey es en dos maneras en lo temer y en lo amar» (Bocados 26: f.44r.). Fuera del ámbito peninsular, el amor al rey encontraba también su sustento teológico en el Policraticus bajo los siguientes términos: "Como imagen de la divinidad el príncipe merece ser amado» (Poli 8,17).

97 Cf. Weber 1964: 194.

98 Sobre este asunto, véase la reflexión sobre la dependencia emocional con el rey más adelante este asunto y consúltese la bibliografía citada en la nota 155 .

99 Part 2,13,14, conviene conectar esta ley con Rom. 13, 1-2.

100 Sobre esta cuestión, cf. Geertz 2003. 
comportaban como les era requerido, ${ }^{101}$ de la misma forma que Cristo lo hacía con quienes no cumplían los sacramentos, según el Setenario. ${ }^{102}$ Más concretamente, si bien fuera de los textos jurídicos de Alfonso X, encontramos un paralelismo interesante entre la ira de Dios sobre el pueblo judío y el daño que infringe el rey fuerte en la General Estoria, bajo los siguientes términos:

Ca pues que fueron ensayados con la set e recibieron ensañamiento e enmienda con la tu misericordia, sopiéronlo por prueva en qué manera serién juzgados con ira los malos sin piadat e cómo serién penados; e proveste a éstos de Israel amonestándolos como padre, e pregunteste a aquéllos, dañándolos como duro e fuerte rey. Ca tan bien los que non eran ý como los que ý estaban todos eran penados a una manera. ${ }^{103}$

Con estas premisas, el rey que exigía la represión brutal de sus súbditos ${ }^{104}$ no se separaba automáticamente del arquetipo divino. Por ello, si bien como regla general el rey no debía tener malquerencia, esto quedaba suspendido ante determinadas circunstancias, contra los autores de grandes yerros:

Mas sin dubda, la deue auer contra los enemigos de la fe. O contra aquellos, que fazen al Rey, o al reyno traycion. O contra los aleuosos, e los falsarios. O contra los fazedores de los otros grandes yerros, que deuen ser escarmentados en todas guisas sin ninguna merced. Ca el Rey contra los malos, quanto en su maldad estouieren, siempre les deue auer mala voluntad, porque si desta guisa non lo fiziesse, non podria fazer justicia complidamente, nin tener su tierra en paz, nin mostrarse por bueno. ${ }^{105}$

Esta obligación del rey de tener malquerencia para "fazer justicia complidamente» nos conduce a un segundo principio de maniobrabilidad política en las Partidas, que tampoco contravenía la imagen religiosa del rey, sino que encontraba en ella su propia justificación. Como fue analizado, la función principal que el monarca tenía atribuida en este código era la de llevar la justicia a su reino, siendo la justicia un concepto ciertamente indeterminado, que otorgaba un amplio espacio al rey para actuar como gobernante, como juez o como legislador bajo el amparo simbólico de estar llevando la justicia de Dios al reino de los hombres. En relación con ello, compartimos la opinión de M. Madero, que compara la definición de justicia dada en el proemio del código de las Siete Partidas («dar a cada vno lo que conviene cumplidamente, e lo que meresce») $)^{106}$ con la del Espéculo («justicia es cosa que da a cada vno ssu derecho»), ${ }^{107}$ para concluir que en las Partidas se

101 Cf. Part, 1,20,21, P 2,5,10, P 2,7,9 y P 2,12,7. Un estudio de la significación y gradación de los términos ira, saña y malquerencia en las Partidas y en los espejos de príncipes lo encontramos en Bizzarri 1995: 67-73.

102 Cf. Set 62. Respecto de la saña de Dios con los que mueren en pecado mortal, cf. S 103.

103 G. Estoria 3,1: 440.

104 Hemos de tener en cuenta que la reacción brutal y sanguinaria era la característica de los reyes sagrados contra sus enemigos, como apreciamos en Bataille 1993: 21-29. Sobre este particular volveremos en el apartado tercero del presente trabajo.

105 Part 2,5,12.

106 Part pr. Véase esta definición también en $P$ 2,1,7 y $P$ 2,13,13. En todo caso, no se pierden por completo los rastros de la anterior definición del Espéculo, que hallamos en P 3,1,1.

107 Esp 4,1,pr. introdujeron connotaciones subjetivas en el concepto de justicia, puesto que bajo la nueva definición ésta no consistía en dar a cada uno su derecho, sino en dar a cada quien lo que conviene y meresce, ${ }^{108}$ y ello claramente otorgaba un mayor espacio para la interpretación del monarca.

Sin embargo, y contraviniendo las obligaciones derivadas de su vicariato divino, fue configurado un supuesto excepcional en la Cuarta Partida que permitía al rey tener malquerencia y no aplicar la justicia. Nos referimos a la facultad que el código alfonsí le confería para vengarse y desterrar sin proceso, por cuestión de malquerencia, y sin argumentar las razones que movían sus actos, a cualquier rico-hombre, tal y como se establecía en la ley $\mathrm{X}$, del título XXV, del libro IV. ${ }^{109}$ Dada su regulación, y que quedaban separadas de este supuesto la traición y la malfetría, ${ }^{110}$ resulta obligado considerar a esta ley como una vía para la actuación arbitraria del monarca contra sus enemigos. Ello, que suponía una transgresión al ideal moral que había de guiar su actuación, encontraba un sustento ideológico en varios espejos de príncipes castellanos de la época, que permitían una reacción arbitraria del rey en contra de sus enemigos $^{111}$. En todo caso, como veremos en el siguiente subapartado, ésta no fue la única ley que colocaba al rey en una situación de difícil concordia respecto de su imagen de vicario de Cristo, por similares razones de índole política, y en beneficio de su situación de poder de cara al resto.

\subsection{Dos casos problemáticos: El rey legisla expresamente en contra de la opinión de la Iglesia}

En este trabajo carece de sentido comentar cada uno de los casos en los que el rey legislador prefirió optar en sus normas por soluciones diferentes a las del derecho

108 Cf. Madero 1996: 451-452. Este principio de operatividad, respecto del amplio margen de interpretación que tenía el rey para aplicar la justicia a situaciones concretas, fue también estudiado por D. Nogales en los espejos de príncipes castellanos, cf. Nogales 2006: 19.

109 Sobre este destierro provocado por la ira del rey, que, no obstante su arbitrariedad, fue suavizado respecto de la situación jurídica previa (particularmente del F. Viejo 1,4,2), cf. Grassotti 1978. Dos ejemplos interesantes de la ira regia aplicada de forma arbitraria se encuentran en la Primera Crónica General, en los relatos de los destierros del Cid ordenados primero por Sancho II y después por Alfonso IV, cf. P. C. General 833 y 850. Sobre este particular, cf. Fournés 2002: 286-287.

110 Gregorio López identifica el término malfetría en este título con cualquier otro delito diferente al de traición, cf. López, G. 1576: glosa Por malfetrias a Part 4,25,11. Bajo esta interpretación, la malquerencia del rey en contra del rico hombre habría de sustentarse en un hecho no delictivo de este último.

111 La posibilidad de actuar con odio y cruelmente por parte del monarca fue estudiada en la literatura sapiencial por D. Nogales, quien articula esta cuestión bajo los pares opuestos de amigo/enemigo registrados en El libro de los doce sabios, y en virtud de los cuales el rey podía abandonar ante algunos hombres el ideal de perfección al que estaba obligado por este texto y reaccionar así de forma contundente cuando la ocasión más lo requería, cf. Nogales 2006: 18-19. En todo caso, aunque la posibilidad de actuar brutalmente contra los enemigos del rey la apreciamos también en otros espejos, lo cierto es que en Bocados de Oro se recogía precisamente la opinión contraria, en función de la cual el rey había de perdonar a sus enemigos y tratarlo con buenas costumbres (cf. Bocados 4: f.9v.), por lo que no podemos considerar ésta como una cuestión pacífica en dicho género literario. 
eclesiástico, ${ }^{112}$ pero nos referiremos por su interés a diversas normas de dos títulos en los que se decidió legislar con carácter expreso en sentido distinto a la opinión de la Iglesia, y que permitían prácticas extendidas y toleradas entre sus súbditos, ${ }^{113}$ pues ponen manifiestamente sobre la mesa unos supuestos problemáticos a la luz del vicariato divino del rey, que no podemos dejar sin análisis.

Así, en primer término, nos detendremos en el título XIV del libro IV de las Partidas, que aceptaba como una institución social digna de amparo jurídico a la barraganía, a pesar de admitir que se trataba de un pecado mortal, en los siguientes términos:

Barraganas defiende santa eglesia, que non tenga ningun christiano, porque biuen con ellas en pecado mortal. Pero los sabios antiguos que fizieron las leyes, consentieronles, que algunos las pudiessen auer sin pena temporal, porque touieron que era menos mal, de auer vna, que muchas. ${ }^{114}$

Efectivamente, de acuerdo con la clasificación de pecados de la ley LXII, del título IV, de la Primera Partida (versión de la Academia), que distinguía entre pecados veniales, pecados criminales y pecados mortales, la barraganía se englobaba en esta última clase, al tratarse de un pecado de obra. ${ }^{115}$ Ahondando en esta cuestión, transcribiremos a continuación otra ley del título dedicado a la barraganía, en la que el legislador expresamente la consideraba como un hecho fuera de mandamiento de eglesia:

E tomo este nome de dos palabras, de barra, que es de arauigo, que quier tanto dezir como fuera: e gana que es de ladino, que es por ganancia, e estas dos palabras ayuntadas quieren tanto dezir como ganancia que es fecha fuera de mandamiento de eglesia ${ }^{116}$.

Bajo el entramado simbólico alfonsí, la barraganía no sólo quedaba fuera del mandamiento de la Iglesia, sino que atentaba contra el plan divino expresado en el libro IV, en la medida en que Dios había instituido el casamiento en el paraíso con la finalidad de que de él "saliese linaje de que el mundo fuese poblado» ${ }^{117}$, sin que con el ayuntamiento de la carne entre marido y mujer se transgrediera la ley de Dios, pues el matrimonio hacía a los cónyuges vivir vida

112 Aunque sí remitiremos al estudio de A. Morín sobre la regulación de las Partidas del ius occidendi en caso de adulterio uxorio, figura que era reconocida como un derecho por el código alfonsí, mientras que, por el contrario, era considerada como un pecado para la mora eclesiástica, cf. Morín 2009: 121-134. En este trabajo, el autor ya sugería como campo a explorar la existencia de una situación semejante en el caso de la regulación de las Partidas de la barraganía, cf. ibíd. 133.

113 Respecto de la tolerancia de buena parte de la población de prácticas o costumbres sexuales prohibidas por la Iglesia, o incluso sobre el rechazo que provocaban estas prohibiciones, cf. Brundage 2000b: 42.

114 Part 4,14,pr. Sobre la trascendencia de esta cláusula y las ventajas sociales de la barraganía, para el reconocimiento de hijos y otras materias, cf. Bazán 2008: 184.

115 Sobre las clasificaciones de pecados en la Primera Partida, cf. Morín 2007.

116 Part 4,14,1.

117 Part 4,pr. Con otras palabras, el mismo proemio del código alfonsí nos indica que Dios «fizo muger que le diesse por compañera en que fiziesse linaje: e establescio el casamiento dellos ambos en el parayso». ordenada naturalmiente, e sin pecado. ${ }^{118}$ La barraganía, en consecuencia, alteraba estos planes y avocaba al hombre a vivir en pecado, como reconocían expresamente las leyes antes expuestas de la Primera Partida. La teoría de la ley de este código establecía que el rey había de tener a Dios ante sus ojos en su tarea legislativa, ${ }^{119}$ pero, como vemos, ello no siempre fue respetado en estas leyes, lo que tiene unas implicaciones que merecen ser tenidas en cuenta.

No obstante, el glosador Gregorio López trató de acomodar esta normativa sobre la barraganía con los mandatos de la Iglesia citando la Suma Teológica de Tomás de Aquino:

(...) et dicit S. Thom. 2. 2. quaest. 69 art. 2. quod quia lex humana non exigit ab homine omnimodam virtutem, quae paucorum est, et non potest inveniri in multitudine populi, quantam habet necesse lex humana sustinere, simplex fornicatio impunita relinquitur. ${ }^{120}$

Sin embargo, a nuestro entender, este intento de concordia resulta infructuoso, puesto que en esta ley el legislador no sólo dejó impune a la simple fornicación, sino que le otorgó cobertura jurídica, convirtiendo así un hecho reconocido expresamente como pecado mortal en una institución con ciertos efectos equiparables a los del matrimonio, como puede comprobarse en este título IV. Ciertamente, esta concordia también podría intentarse acudiendo al siguiente canon del Decreto de Graciano: «Is, qui non habet uxorem, et pro uxore concubinam habet, a communione non repellatur; tamen ut unius mulieris, aut uxoris concubinae, sit coniunctione contentus», ${ }^{121}$ pero las Partidas tenían una concepción de la barraganía como pecado mortal y atribuían a la Iglesia un rechazo absoluto de esta práctica, por lo que poco nos aportan las opiniones de teólogos o canonistas que no respondían a este patrón dentro de la Iglesia. ${ }^{122}$

En nuestra opinión, para interpretar el contenido de esta ley hemos de alejarnos por un momento tanto de la doctrina eclesiástica, como del análisis estrictamente jurídico, y aproximarnos a la literatura de espejos, que nos da las claves para comprender la actuación del rey en sus distintas facetas, también como legislador, y nos ayuda a dibujar las tramas de significación que facilitan la interpretación de estas normas problemáticas. Concretamente, a los efectos de este trabajo, conviene que nos detengamos en una máxima contenida en el capítulo Del rey y de su reino de la colección de producción castellana Flores para la filosofía, en virtud de la cual el rey no debía descuidar a los pecadores e incluso debía hacerles bien, máxima recogida en los siguientes términos: "Al rey deue venir miente de fazer merçed a los peccadores». ${ }^{123}$

Dicha sentencia contribuía a ensanchar el campo de actuación política del rey en su reino, permitiéndole con

118 Ídem.

119 Cf. Part 1,1,11.

120 López, G. 1576: glosa Pena temporal a Part 4,14,pr.

121 D. Graciano D. 34, c.4.

122 La posición de la Iglesia sobre la barraganía no fue fijada con claridad hasta concluida la Edad Media, en el concilio de Trento. Sobre las distintas posiciones dentro de la Iglesia al respecto, cf. Rodríguez Gil 1998: 66-84.

123 Flores 3,6. En la versión del códice 9428 de la Biblioteca Nacional se dice de forma muy similar: «E toda uja deue le venjr emjentes de fazer bien e merçed alos peccadores», cf. Lucía Mejías 1997. 
su magnanimidad ganarse el favor de sus súbditos, incluso de aquellos que no actuaban conforme a los mandatos de la Iglesia, lo que había de contribuir al sometimiento pacífico del reino. A esta conclusión nos ayudan a llegar los espejos de origen oriental, puesto que en Poridat de las poridades se articula expresamente el perdón real como medio para evitar levantamientos del pueblo ${ }^{124}$ y en el Libro de los buenos proverbios como vehículo para acrecentar el reinado ${ }^{125}$, lo que, evidentemente, nos marca una relación del rey con los pecadores construida sobre criterios políticos. Por su parte, en Bocados de Oro se justifica que el rey cerrase los ojos y perdonase algunos yerros de sus súbditos por dos razones, una que encaja con su rol salvífico («e con esto enderesçaranse los sus coraçones e aliuiarse ha todo su fecho») y otra de índole política («E si los mucho escatimares, embargaran el tu seso») $)^{126}$. Tomando estas reflexiones en consideración, no podríamos desconocer que las gracias o mercedes hechas por el rey en las Partidas a favor de los pecadores, incluidos los que practicaban la barraganía, también tendrían un trasfondo de esta naturaleza, que justificaría la transgresión de la mencionada ley $\mathrm{XI}$, del título I, del libro I, sobre criterios de oportunidad política.

En cuanto al segundo caso problemático, dentro del título dedicado al adulterio del libro VII, se aprecia cómo las Partidas otorgaban acción al marido contra su mujer adúltera, mientras que, siguiendo la opinión de los sabios antiguos, no se otorgaba la misma facultad a la mujer agraviada por el adulterio de su cónyuge, bajo la aclaración de que estaba legislándose en contra del juicio de la Iglesia ${ }^{127}$, si bien, téngase en cuenta, estamos ante una cuestión meramente procesal, que no despenalizaba el adulterio del marido, ni afectaba al derecho divino:

(...) E por ende dixeron los sabios antiguos, que maguer el ome casado yoguiesse con otra mujer que ouiesse marido, que non lo puede acusar su muger, ante el juez seglar sobre esta razon como quier que cada vno del pueblo (a quien non es defendido por las leyes deste nuestro libro) lo puede fazer. E esto tuuieron por derecho por muchas razones (...) e esto fue establecido por las leyes antiguas, como quier que segunt juyzio de santa yglesia non seria asi. ${ }^{128}$

Ésta era la misma solución adoptada por la Lex lulia de adulteriis coercendis, que sirvió de clara inspiración para la

124 Cf. Poridat 2: 113.

125 Cf. L. B. Proverbios 18.

126 Cf. Bocados 14: f.28r.

127 Respecto de las leyes eclesiásticas y de la opinión de la Iglesia sobre el adulterio masculino, véase la regulación de la materia del canon XXXII del Decreto de Graciano, así como las obras de Brundage 2000a: 86, 257, 381-382 y 445 y Morín 2009: 104-113.

128 Part $7,17,1$. El contenido de esta norma ya se encontraba brevemente anunciado en $P$ 4,9,13. A. Morín detecta esta divergencia explicita entre las Partidas y el derecho canónico y la analiza bajo la lógica de los distintos fueros, ya que en la práctica jurídica de la época se otorgaba al fuero secular la competencia en caso de acusación criminal y al eclesiástico en caso de acción de divorcio (cf. Morín. A. 2009: 111-113), como ocurría en las Partidas, que otorgaban jurisdicción a los jueces seculares para el primer supuesto (cf. Part $7,17,4$ ) y a los eclesiásticos para el segundo (cf. P 4,9,pr.), en el que sí se concedía acción a la mujer ante el adulterio de su marido (cf. P 4,2,8). regulación de este título. ${ }^{129}$ Por otra parte este título seguía la tradición foral castellano-leonesa de no considerar a la mera relación sexual extraconyugal del marido como digna de reproche penal, aunque algunos fueros sí imponían una pena al marido cuando su relación ilícita no sólo era estable, sino que adquiría una naturaleza pública, ya porque tuviese barragana o concubina paladina. ${ }^{130}$

En todo caso, en este último punto no se legislaba expresamente contra la opinión de la Iglesia y, además, es posible una concordia con la misma, en tanto que resulta plenamente de aplicación la glosa Pena temporal del jurista Gregorio López al proemio del título XIV del libro IV,, ${ }^{131}$ en la medida en que las Partidas, si bien no configuraban como delito la fornicación extramatrimonial del marido, no convertían un pecado mortal en un derecho respaldado por una institución con ciertos efectos civiles, como ocurría en el anterior título. En consecuencia, sólo el primero de los casos estudiados plantea un conflicto expreso y frontal con la teoría de la ley de las Partidas y con las obligaciones del rey, en cuanto que vicario de Dios en su reino, y únicamente con la ayuda de la literatura de espejos podemos entender el trasfondo político que subyace bajo sus normas.

\section{LA CONFIGURACIÓN DE LA NATURALEZA DEL REY BAJO ESQUEMAS DE SACRALIDAD}

Como hemos visto hasta el momento, las Partidas reconocían el carácter del rey como vicario de Dios e intermediario entre los planos sagrado y profano de la realidad, lo que tenía unas consecuencias lógicas que fueron aquí expuestas. Más allá de esto, sobre la base de distintos datos y evidencias, entre las que se encuentran precisamente algunas de estas leyes, se ha producido un extenso debate en la historiografía sobre el carácter sagrado o no de Alfonso $X$ en particular y de la monarquía castellana en general. ${ }^{132}$ Discernir la naturaleza otorgada al rey en

129 De hecho, hemos de interpretar que cuando las Partidas esgrimían como fuente de autoridad a los sabios antiguos en este título realmente estaban aludiendo a los juristas romanos. En este sentido, conviene conectar la mención a los sabios antiguos en Part 7,17,1 con la equivalente de C. Justiniano 9.9.1 y la de Part 7,17,13 con Dig. 48.5.24 (23).

130 Éste es el llamado por E. Gacto adulterio continuado, por contraposición con el adulterio simple (cf. Gacto 1971: 907-923). Dentro de la familia de Cuenca-Teruel, se establecía una pena al marido por el llamado adulterio continuado en las siguientes leyes: F. Cuenca 289 $(11,37)$, C. Valentino 2,1,30 y 2,1,31, F. Iznatoraf 259, F. Andújar 249, F. Zorita, 261, F. Alcaraz 4,38, F. Alarcón 245, F. Úbeda 28,5, F. Baeza 259, F. Plasencia 100, F. Béjar 335, F. Sabiote 260, F. Brihuega 99 y F. Huete 218.

131 Cf. nota 121 y texto principal del que depende.

132 J. M. Nieto Soria es el máximo representante de la línea de investigación que defiende el carácter sagrado de la monarquía casteIlana, pero esta corriente no ha estado exenta de críticas, como la realizada por P. Linehan, quien entiende que las diferentes afirmaciones en las leyes y en otros documentos sobre el origen divino del poder $y$ el reconocimiento del vicariato divino de Alfonso $X$ no tienen la transcendencia dada por el autor español en su obras. P. Linehan se muestra particularmente crítico con el concepto propuesto por Nieto Soria para la realidad castellana de unción privada del rey, en base a la cual éste no necesitaría de la ceremonia pública de la unción para que sus súbditos lo tuviesen como ungido por Dios, cf. Linehan 2011: 452-470. Un resumen solvente de las distintas posiciones enfrentadas podemos encontrarlo en Kleine 2014a: 20-27. 
el entramado simbólico de las Partidas no está exento de utilidad, pues nos permite enriquecer el contenido del vicariato divino afirmado por este código, así como, entre otras varias cuestiones que iremos desarrollando, nos ayuda a analizar la estrategia de dominación simbólica emprendida por Alfonso $X$ sobre su pueblo.

En esta labor de averiguación, en un primer término nos sumiremos en la propia terminología empleada por el legislador, para lo cual acudiremos al título XVIII del libro I de las Partidas, que se ubicaba en el epicentro de la cuestión, pues regulaba el delito de sacrilegio entendido como "tomar sin derecho cosa sagrada, o dañar, o fazer daño en ella». ${ }^{133}$ En dicho título hallamos un conjunto de personas y de cosas poseedoras de naturaleza sagrada, que merecían la protección del legislador, entre las que apreciamos a los clérigos y religiosos, pero también a las iglesias, los cálices, las cruces y otros objetos, que no reclaman nuestra atención en este punto. Sin embargo, la ley XI del mencionado título sí resulta particularmente interesante, pues en ella se regulaban hechos semejantes al sacrilegio en un intento de apropiación por parte del rey de los esquemas teológicos de la Iglesia, ${ }^{134}$ bajo la siguiente formulación: "Nome e semejança de sacrillejo, han otros yerros, que fazen los omes, o dizen sin razón, e sin derecho sin los que son dichos, en la ley ante desta. E non les llaman, nin les dizen de llano, sacrillejo: mas son yerros, muy cerca o semejantes dellos». Entre estos hechos cercanos al sacrilegio se hallaban el de porfiar o contender «contra el juyzio, o establescimiento, que ouiesse fecho el Papa, o el Emperador, o el Rey, diziendo a sabiendas mal dello», así como el de meter «bollicio, entre las gentes, ayudandolas contra el Rey, o contra la tierra por meter desacuerdo, o fazer daño en ella», por lo que, si bien estos actos realizados en contra del emperador o del rey no eran estrictamente sacrilegios según la literalidad de esta redacción, sí eran actos considerados como semejantes, lo que nos marca una naturaleza de estas figuras que, como mínimo, y atendiendo exclusivamente a lo dispuesto en dicho título, se situaba próxima a la sagrada. ${ }^{135}$

\section{Part 1,18,1.}

134 A. Ferrari fue pionero en analizar cómo la legislación del rey se aprovechó de estos esquemas y conceptos teológicos a su favor, entre ellos precisamente el de la figura del sacrilegio, cf. Ferrari 1934: 455. Desde una perspectiva más amplia, respecto de la influencia de los esquemas teológicos sobre el derecho del siglo XIII, cf. Boureau 1992a. Con posterioridad a las Partidas, en el Setenario también aparecería contemplado el pecado de sacrilegio, como uno de los siete tipos de pecados posibles, sin embargo no se haría mención alguna a estos hechos que en las Partidas eran como sacrilegios (cf. Set 98).

135 Dado que los hechos realizados en contra del rey no tenían aquí la consideración de sacrilegios en sentido estricto, no podemos llevar nuestras conclusiones tan lejos como J. M. Nieto Soria, quien considera la inclusión del rey en este título dedicado al sacrilegio como un reconocimiento de su carácter sagrado (cf. Nieto Soria 1997: 84-85). De todas formas, lo cierto es que la ley XI tenía una redacción ciertamente problemática, puesto que, a pesar de no considerar estos actos como sacrilegios en sentido estricto, tampoco excluía que las personas o cosas que amparaba tuviesen naturaleza sagrada, ya que tanto el papa como los artículos de fe eran protegidos por la misma, y ambos tenían el reconocimiento de sagrados bajo este título (cf. Part 1,18,1 y $\mathrm{P} 1,18,11$ ). En este título, la solución de las Partidas se apartaba del derecho visigodo, que consideraba como sacrilegio en sentido estricto al yerro en contra del rey, cf. L. ludiciorum PT 9. Por su parte, dentro de la legislación de Alfonso X, en el Fuero Real se disponía que el traidor merecía la pena «de aquel que hace sacrilegio» (F. Real 1,2). En lo que
En todo caso, lo dicho no resuelve plenamente la cuestión que nos convoca, por ello acudiremos a la regulación sobre la unción regia. De esta manera, desembocamos en la ley XIII, del título IV, del libro I, que describía las nuevas formas de la ceremonia de unción de los reyes, con óleo sagrado sobre el hombro del brazo derecho, donde Cristo portó la cruz, y no ya sobre sus cabezas, como ocurría en tiempos antiguos. ${ }^{136}$ Para extraer información relevante a los efectos del presente estudio, hemos de conectar esta declaración con lo dispuesto por el legislador años después en el Setenario, en virtud de lo cual, la unción de los reyes era obligatoria ${ }^{137}$ y por la misma se convertían en sagrados, puesto que con el ungüento de la crisma se sagraban las cosas. ${ }^{138}$ Sin embargo, y a pesar de la claridad de la norma, dicha afirmación tampoco cierra la problemática, en la medida en que, de acuerdo con la misma ley del Setenario, todos los cristianos adquirían la condición sagrada por medio de la crisma del bautismo. A causa de la unción, por consiguiente, el rey no alcanzaba una naturaleza diferente a la de sus súbditos, y ello, al menos aparentemente, diluía

respecta a la literatura de espejos europea, en el Policraticus se describen determinados actos en contra del rey con la misma expresión que la utilizada después en las Partidas de hechos semejantes al sacrilegio, cf. Poli 6,25. Respecto de la posible existencia de una sacralidad no plena asociada a la realeza, en el ámbito español, si bien de una manera más intuitiva que analítica, F. Tomás y Valiente entiende que el derecho penal castellano reflejaba una naturaleza casi sagrada del rey, que consideraba propia de un sistema de personalización absoluta del poder, y que se manifestaba en el ámbito de los delitos de lesa majestad humana (cf. Tomás y Valiente 1969: 23), mientras que J. Iturrioz, refiriéndose concretamente a la regulación de las Partidas, otorgaba una naturaleza casi sagrada al rey tal y como fue configurada su figura (cf. Iturrioz 1955: 76). En lo que respecta al ámbito europeo, diversos son los trabajos que podrían citarse, pero, al menos, conviene mencionar el análisis de E. H. Kantorowicz sobre la teoría política de Bracton y la asociación del príncipe con el fisco, entendida como una entidad de naturaleza cuasi sagrada (cf. Kantorowicz 1985: 162-187, especialmente la página 186, en la que llega a describir al rey como un vicarius Fisci), así como el de A. Boureau, que establece distintos grados de acceso a lo sagrado, adjudicando al rey una sacralidad disminuida o difusa, en tanto que delegada por la autoridad eclesiástica (cf. Boureau 1992b).

136 En la redacción de esta ley del manuscrito Add. 20787 del British Museum de la Primera Partida se establecía con un carácter imperativo que "esta unción se deue fazer, segund dize en el segundo libro», pero en ninguno de los manuscritos que se conservan de la Segunda Partida se desarrollaba este particular. Por lo tanto, si bien se valoró en un principio, finalmente no llegó a elaborarse el ritual de la unción en las Partidas, como se apunta con buen criterio en O'Callaham 1999: 47. Por su parte, J. M. Nieto Soria (1997: 81-83), con indudable brillantez, lleva más lejos su análisis e interpreta esta omisión bajo su tesis de la unción privada del rey castellano, por la que éste no precisaba de ceremonia alguna para ser considerado como ungido por Dios. Dada las limitaciones de extensión propias de este artículo, desarrollaremos nuestra opinión sobre este concepto de la unción privada del rey en un próximo trabajo, dedicado a esta cuestión.

137 «Et que los rreyes deuen sser vntados, muéstralo Ysayas en nombre de Ihesu Cristo ( )» (Set 89), sobre este particular, cf. Nieto Soria 1988: 63. En este punto, P. Linehan entiende esta expresión como un ejemplo de conjugación verbal en presente histórico y por lo tanto no considera que la unción regia se estableciera como obligatoria (cf. Linehan 2011: 465-469). Sin embargo, en este análisis, el autor pasa por alto que la mencionada ley LXXXIX describía asimismo la unción de los reyes de agora, como bien se apunta en Kleine 2014a: 14, lo que, a nuestro entender, convierte la remisión bíblica de Isaías en un exhorto para el presente.

138 Cf. Set 89. 
tanto el reconocimiento de su carácter sagrado efectuado en esta norma, ${ }^{139}$ como los efectos sacralizadores que pudieran derivarse de la unción descrita en la ley XIII, del título IV, del libro I de las Partidas.

Para encontrar respuesta al asunto que nos atañe, varios investigadores han trabajado con algunos requisitos que, inspirados en los modelos francés e inglés, entendían necesarios para otorgar un carácter sagrado al rey castellano, tales como la unción, la consagración, la coronación, los poderes milagrosos y la existencia de un panteón real. ${ }^{140}$ Nosotros, en cambio, rechazamos que estas expresiones de sacralidad hayan de ser consideradas como requisitos para apreciar la existencia de reyes sagrados en el resto de la Europa occidental. Por el contrario, compartimos el criterio propuesto por el sociólogo E. Durkheim para discernir de manera universal entre lo sagrado y lo profano, cual es el del carácter absolutamente heterogéneo de lo sagrado, que se traduce en una naturaleza diferente y separada de la profana, que en cada sociedad se manifiesta de una manera determinada, pero que necesita de unos tabúes de contacto que lo preserven. ${ }^{141}$ Inspirados en este autor, y en otros

139 P. Linehan (2011: 467) defiende que el mencionado carácter sagrado del rey, a través de la unción, pierde su transcendencia política al adquirirse mediante el sacramento del bautismo, que estaba a disposición de todos los cristianos con los mismos efectos sacralizadores, con lo que no ha de interpretarse esta ley como un argumento a favor del carácter sagrado de la monarquía castellana, como sostiene J. M. Nieto Soria. No obstante, para M. Kleine (2014a: 13-14), la unción regia en el Setenario era un sacramento distinto del bautismo, y simplemente estaba ubicado dentro de éste para no romper con el número de siete sacramentos propio del esquema setenario de la obra. Según la autora, en todo caso, esta unción regia se acercaría más al sacramento de la confirmación, ya que ambos únicamente podían oficiarse por obispos o superiores. En nuestra opinión, ya fuera esta ceremonia de la unción regia un sacramento propio en el Setenario, o bien una forma de otro sacramento, lo cierto es que por la crisma se hacían sagrados todos los cristianos bajo la literalidad de la ley LXXXIX y ello, aparentemente, diluía los efectos sacralizadores de la crisma en todos sus usos. Sin embargo, esto sería merecedor de una reflexión más serena, puesto que ya demostró E. Durkheim la existencia de religiones en las que todos los fieles tenían la condición sagrada, e incluso en el mismo cristianismo no sólo los fieles, sino todos los hombres son en alguna medida sagrados, en tanto que tienen alma, cf. Durkheim 1968: 139, 145-146.

140 En concreto, éstos son los que menciona Rucquoi 1992: 78, que son similares a los mencionados con anterioridad en Ruíz 1985 109-110. Véase la crítica a este encorsetado esquema de actuación de Nieto Soria 1997: 99. Sobre este asunto de los requisitos exigidos para la consideración sagrada del rey en la monarquía castellana, cf. Kleine 2014a: 3. Por otra parte, los autores contrarios al carácter sagrado del rey castellano se muestran claramente influenciados en Los reyes taumatúrgicos de $\mathrm{M}$. Bloch, pero el propio historiador francés reconocía en este texto la existencia de reyes sagrados sin poderes taumatúrgicos (cf. Bloch 2006: 128) e incluso identificaba la procedencia de la sacralidad regia, en su mayor parte, en ciertas creencias populares de origen arcaico (quizás aquí pueda rastrearse una influencia durkheimiana, respecto de la sociedad como fuente de atribución de la sacralidad. Sobre la influencia de E. Durkheim en M. Bloch, cf. nota 141), además de en el rito cristiano de la unción (cf. Bloch 2006: 148).

141 Cf. Durkheim 1968: 42-43. Este autor elaboró una teoría sobre la religión que tuvo gran repercusión entre los investigadores y que aún hoy inspira multitud de trabajos de distintas ramas de las ciencias sociales (sobre sus influencias y los recientes análisis neodurkheimianos, cf. Ramp 2010). A pesar de ello, sus trabajos sobre este asunto no han estado exentos de críticas, una de las más usuales, respecto de la dualidad planteada entre lo sagrado y lo profano, consiste en afirmar que no en todas las sociedades existe esta separación en dos trabajos de sociólogos y antropólogos, que contraponen las categorías sagrado/profano como herramientas útiles de sus análisis, podremos abordar esta problemática sin sentirnos atados por los requisitos preestablecidos por algunos historiadores para la monarquía castellana, y podremos entonces dilucidar si los reyes habían sido configurados en las Partidas bajo un esquema de plena sacralidad o bien bajo una forma de sacralidad disminuida, pues la mera lectura de la mencionada ley XI, del título XVIII, del libro I, como vimos, no resolvía esta problemática. En todo caso, esta operación no nos desvelará la opinión que del rey tenía su pueblo, que es la fuente única de sacralidad de las ideas, personas y $\operatorname{cosas}^{142}$, pero sí nos informará sobre la estrategia de dominación simbólica del monarca y sobre su intento de orientar las creencias de su pueblo hacia espacios de su conveniencia.

No repetiremos en este punto todolo dichoanteriormente respecto del vicariato divino del rey, que hacía de él un instrumento de Dios para llevar la justicia celestial al reino terrenal, lo ubicaba en la cúspide del reino y le confería una naturaleza que difería radicalmente de la de sus súbditos. ${ }^{143}$ Entre la posición del rey, que se manifestaba esencialmente en su carácter como vicario de Dios en lo temporal, y de forma derivada en sus enormes atribuciones de hecho y de derecho, en sus maneras alejadas de las del común, ${ }^{144}$ en sus coronas de oro, ${ }^{145}$ en su majestad, ${ }^{146}$ en su propio

planos de la realidad, y que, por lo tanto, su modelo interpretativo no resulta universalmente aplicable. Para ver una síntesis de estas críticas, cf. Coleman y White 2006: 72-73. Por otra parte, nuestro trabajo no es original al aplicar a la figura del rey del Antiguo Régimen una concepción de lo sagrado deudora de los trabajos de E. Durkheim, pues, desde distintas aproximaciones al fenómeno religioso, tanto $\mathrm{R}$. Caillois (1984), como G. Bataille (1993) y G. van der Leeuw (1964: 105121), entre otros, lo hicieron en sus textos y, desde la historiografía, ya lo citasen o no expresamente, varios autores de referencia también emprendieron esta senda, como M. Bloch respecto de los reyes taumaturgos (cf. Colberty Rhodes 1978), M. Walzer, al analizar la figura de los reyes sagrados franceses (cf. Watts Miller 1996: 241-242), así como, más recientemente, L. Hunt (2001, v.2: 74-91) respecto del rey de Francia en el contexto de la revolución francesa, por citar varios de los autores indispensables del repertorio bibliográfico.

142 Cf. Durkheim 1968: 234.

143 Cf. nota 45.

144 Cf. Part 2,5. Respecto del alejamiento de las maneras del rey sagrado de las del común de sus súbditos, cf. Caillos 1984: 102-103.

145 Cf. Part 2,5,5, que expresamente vinculaba estos objetos con la figura del vicariato divino. Para R. Caillois, los objetos de poder regio representaban un signo de la vinculación del rey con lo sagrado, puesto que «el rey lleva la corona, el cetro y la púrpura reservada a los dioses» (Caillois 1984: 99); véase también Leeuw 1964: 107. Esta reflexión sobre dichos objetos es realizada asimismo por una diversidad de historiadores, concretamente, un estudio que analiza esta cuestión respecto de la Edad Media española es el de Delgado Valero 1993-1994.

146 Como se explicará en la nota 168, los delitos contra el rey recogidos en la Séptima Partida recibían el nombre de delitos de lesa majestad. Más allá de esto, las notas de grandeza y dignidad asociadas a la majestad quedaban vinculadas con el rey en las Partidas por doquier, no en vano ocupaba el lugar de Dios en su reino, sus órdenes no podían ser desobedecidas, sus súbditos habían de amarlo y temerlo, su cabeza se coronaba con objetos asociados al vicariato divino, poseía unas lujosas vestimentas exclusivas y un largo etcétera de circunstancias que hemos tenido la oportunidad de mencionar en el presente trabajo. Por ello, rechazar la majestad del rey castellano en el scriptorium alfonsí, como parece sugerir T. Ruíz, por el hecho de que algunas cantigas de Santa María retratasen los temores y flaquezas de 
nombre de rey ${ }^{147}$, en los tabúes asociados a su figura ${ }^{148} \mathrm{e}$ incluso en las vestimentas que le eran exclusivas y que resaltaban su solemne magnificencia, ${ }^{149}$ y la de sus súbditos, existía un abismo cargado de significado. Por otra parte, a la luz de las estructuras simbólicas que nos proporciona la legislación alfonsí previa, en el plano conceptual, según el Espéculo, el rey tenía un carácter preexistente al de su reino, que se definía por el rey, ${ }^{150}$ además era dador de vida del pueblo ${ }^{151}$ y todos los otros hombres adquirían por él la entidad de ser una cosa ${ }^{152}$ mientras que en el Fuero Real se aprecia cómo el rey no era una derivación de su pueblo, sino que éste tenía en él su comenzamiento, al igual los ángeles y arcángeles lo tenían en la divinidad. ${ }^{153}$ En consecuencia, en este entramado previo, el monarca se concebía como una figura preexistente, de la que dependían su reino y su pueblo, de la misma manera que las cosas sagradas generan una relación de dependencia sobre otras, específicamente el rey numinoso o sagrado sobre sus sometidos, lo que analiza con solvencia G. Widengren. ${ }^{154}$

Si nos centramos en las Partidas, el carácter preexistente del rey puede rastrearse en la ley $\mathrm{VI}$, del título XIII, del libro II, entre otras normas, ${ }^{155}$ mientras que las relaciones de dependencia ontológica entre el rey y su reino o su pueblo se articulaban, además de por la anterior norma, por una serie de imágenes alegóricas, dos de las cuales serán aquí rescatadas. En primer lugar, mencionaremos la imagen del monarca como señor del reino, representado como una huerta necesitada de dueño y de los cuidados ordenados por éste, ${ }^{156}$ sin los cuales toda huerta pierde su condición de tal. $Y$, en segundo lugar, tenemos la imagen del monarca

Alfonso X (cf. Ruíz 1985: 131), supone, a nuestro juicio, una conclusión precipitada.

147 Cf. nota 8.

148 Una reflexión detenida sobre este asunto se realizará más adelante, dentro de este mismo apartado 3, del presente artículo.

149 Cf. Part 2,5,5. Sobre las vestimentas del rey sagrado en los estudios sobre religión, cf. Otto 1965: 96 y Caillois 1984: 50.

150 Esp 2,1,2: «Rey tanto quiere dezir como governador de pueblos, e el regno lieva nonbre del Rey, ca por el rey es dicho regno». Sobre esta norma y sobre la naturaleza del rey en la legislación alfonsí, particularmente en función de lo que se deriva de E 2,1,4 y F. Real 1,2, reflexiona con acierto González Alonso 1988, v. 2: 208.

151 Cf. Esp 2,1,4: «( ) ca asi como el cuerpo vive por el alma asi el pueblo vive por el rey». En este mismo sentido, cf. E 2,1,1: «El rey es cabeza de su reyno e es ayuntamiento de su pueblo e vida e asentamiento dellos ( )".

152 Cf. E 2,1,1: «E rey es mayor sobre todo su regno por quien todos los del regno reciben dono de Dios en seer una cosa». Véase también Esp 2,1,4 y E 2,1,6.

153 Cf. F. Real 1,2.

154 Cf. Widengren 1976: 360-361. En un sentido más genérico, respecto de la relación de dependencia de lo profano respecto de lo sagrado, cf. Otto 1965: 19-23, que reinterpreta el concepto de sentimiento de criatura de F. Schleiermacher, Durkheim 1968: 42, 218-219 y Caillos 1984: 11.

155 Según esta norma, los que matasen al rey, eliminarían «aquella cabeça, que Dios les diera: e la vida porque biuen en vno». B. González Alonso interpreta el carácter de dador de vida del rey a su pueblo en el Espéculo como una muestra de la preexistencia conceptual del rey (cf. González Alonso 1988: 208). En el presente trabajo, y dado que estamos de acuerdo con el autor, proponemos la misma interpretación para esta norma de las Partidas. Por otra parte, la idea de preexistencia regia quedaba también reflejada en la caracterización del rey como comenzamiento del resto, cf. P 2,1,pr.

156 Cf. Part 2,10,3. como corazón del pueblo, bajo el entendido de que los miembros carecen de unidad de cuerpo sin corazón. ${ }^{157}$

Por otra parte, y respecto a la dependencia con el rey, no sólo por su figura existían el reino y el pueblo, sino que, en un sentido amplio, la suerte de sus súbditos pendía del comportamiento del monarca, que era el espejo en el que se miraba el resto, como puede inferirse de lo dispuesto en la ley IV, del título V, de la Segunda Partida y de lo establecido, fuera de ella, en la Primera Crónica General así como en los espejos de príncipes de la época, que tanto ayudan en la tarea de contextualización e interpretación. ${ }^{158}$ La dependencia con el rey tenía, por lo tanto, diferentes vertientes en este código, sin embargo nos interesa especialmente la variante emocional de la misma, que era vehiculada a través de los polos amor/temor, bajo un movimiento de atracción y otro de rechazo que son los que genera el fenómeno de lo sagrado en el hombre, como sostienen un elevado número de investigadores, ${ }^{159}$ y que, según las Partidas, habían de experimentar todos por Dios, ${ }^{160}$ así como los súbditos por su rey. ${ }^{161}$

En este código, nos encontramos, desde el punto de vista conceptual, ante un rey con carácter previo a su pueblo, que servía como principio vital del mismo, y, en el terreno de la práctica, separado simbólicamente de los súbditos por un conjunto de normas que restringían el contacto. Esta preexistencia y su carácter de dador de vida o aglutinador del pueblo lo presentaban, bajo el esquema de E. Shils, como un ser cargado de carisma $a^{162}$ y justificaban la dependencia ontológica entre el monarca y su pueblo, que había de obedecerlo en todo momento, ${ }^{163}$ así como amarlo y temerlo, pero ante el que tenía que ser resguardado de cualquier ataque o contacto ilegítimo. En este punto, nos detendremos, aunque sea someramente, en explicar la excepcional protección que conferían estas leyes al rey, asociando su figura a unas prohibiciones que se desplegaban sobre distintos campos, siguiendo el tabú bíblico de tocar a los ungidos por Dios ${ }^{164}$ y que encuentran su mejor

157 Para las Partidas el rey era el corazón del pueblo, en el entendimiento de que por el corazón «reciben todos los otros miembros vnidad, para ser vn cuerpo» (P 2,1,5).

158 Véase lo referido sobre este asunto en el punto 2.1 del presente artículo.

159 La fuerza emotiva que despliegan en los hombres las cosas sagradas ha sido un tema tratado por los investigadores en profundidad, y desde diferentes ámbitos, como puede comprobarse en Otto 1965: 53-54; Durkheim 1968: 418-420; Leeuw 1964: 38-41 y Bataille 1993: 17. Para un análisis más reciente sobre el tema, que aborda la vinculación entre lo sagrado y lo emocional tomando el ritual como eje, cf. Alcorta y Sosis 2005.

160 Cf. Part 2,12.

161 Véase lo referido sobre este asunto al final del punto 2.1 dentro del presente artículo.

162 Para su redefinición del concepto weberiano de carisma bajo criterios de centralidad simbólica, cf. Shils 1965: 199-213. Un estudio que emplea esta redefinición del término carisma para analizar la figura de diferentes reyes es el de Geertz 1985. Respecto de los conceptos empleados en el presente estudio, un trabajo que confronta la sacralidad de E. Durkheim y el carisma de E. Shils es el de Garland 2006: 75-76.

163 Cf. notas 87,88 y 89, así como el texto principal del que dependen. Sobre la obediencia al ser sagrado, R. Caillois (1984: 99) interpreta que el hombre que posee maná es el que sabe hacer obedecer al resto.

164 «Nolite tangere christos meos» («no toquéis a mis ungidos»), Salmos, 105 (v. 104), 15; I Cron., 16, 22. Sobre esta referencia bíblica, 
interpretación en relación con la necesidad de proteger al ser sagrado. No en vano, el daño al rey perjudicaba, según esta normativa, no sólo al rey y a la divinidad misma, sino al pueblo en su conjunto, ${ }^{165}$ lo que puede explicarse acudiendo a la célebre identificación entre lo sagrado y lo social bajo la óptica durkheimiana. ${ }^{166}$ Sobre estas premisas, y desarrollando lo dispuesto en la legislación alfonsí previa, ${ }^{167}$ las Partidas exhortaban a los súbditos del rey a no hacerle ningún mal ya fuera de hecho o de palabra ${ }^{168} y$, en el fuero interno, a no desearle daño alguno, ${ }^{169}$ si bien sólo ante los dos primeros supuestos se configuraba una reacción penal como respuesta. ${ }^{170}$

cf. García-Pelayo 1959: 119. Esta cita bíblica era conectada en el Liber ludiciorum directamente con el delito de traición, cf. L. Iudiciorum PT 9. En cuanto a la fenomenología de la religión y respecto de la distancia que ha de guardarse con los reyes, entendidos como seres sagrados, y los tabúes asociados a éstos, cf. Leeuw 1964: 34 y 105-121.

165 Cf. Part 7,2,1. En esta ley se decía que los traidores dañarían con su acción a la divinidad, al rey y a todos los omes, mientras que en $\mathrm{P}$ 2,13,6, como veremos, se aludía al reyno como parte ofendida, en lugar de a todos los omes, y además se mencionaba el daño que se autoinflingía el propio traidor con su yerro. Por su parte, en P 2,13,26 expresamente se aludía al reino y al pueblo como perjudicados por el ataque al rey. Sobre la asociación entre el rey y el reino en los espejos de príncipes, cf. Flores 3,1: «El rey e su reyno son dos cosas e commo una persona, ansy commo el cuerpo e el alma son vna cosa», para ampliar este tema, véase el apartado 1,1 del presente trabajo, sobre la imagen corporativa del reino, tanto en las leyes como en los espejos de príncipes.

166 La identificación de lo sagrado con la sociedad misma es una idea central y recurrente en Durkheim 1968, y la base de numerosos trabajos inspirados en éste, a partir de entonces, cf. nota 141.

167 Cf. F. Real 1,2 y Esp 2,1 y E 2,2.

168 Los diferentes tipos penales que concretaban ello y las penas correspondientes quedaban disgregadas por todo el código, pero principalmente se establecían en los títulos XVIII del libro I, XIII del libro II, XXV del libro IV y II del libro VII. No nos detendremos en desarrollar los cuatro títulos mencionados, pues un estudio detallado de esta vasta regulación desbordaría el objeto del presente trabajo. En todo caso, el análisis más interesante de las distintas formas de traición en las Partidas y de sus antecedentes normativos en Castilla es el de Iglesia Ferreiros 1971. La traición en la Castilla medieval no es una materia sobre la que exista un gran volumen de publicaciones por parte de los juristas, pero puede encontrarse una bibliografía útil, aunque incompleta, en Villarroel González 2008: 271. Lo que sí conviene resaltar en este punto es que el título II de la Séptima Partida regulaba una serie de hechos delictivos bajo el nombre de delitos de lesa majestad, que, si bien aludía a una majestad humana, empleaba un vocablo que evoca una vinculación con lo sagrado para diversos autores. En este sentido, para R. Otto la majestad constituye uno de los aspectos de lo sagrado o lo numinoso (cf. Otto 1965: 37), mientras que para E. Durkheim la idea de majestad es esencialmente religiosa (cf. Durkheim 1968: 65). En esta línea, y en cuanto al delito de lesa majestad, para R. Caillois (1984: 20) constituye un atentado contra lo sagrado y contra el orden de universo. Dentro de la doctrina jurídica española, F. Tomás y Valiente entiende que los delitos de lesa majestad humana eran diferentes a los de lesa majestad divina, pero estaban enlazados en el derecho del Antiguo Régimen (Tomás y Valiente 1969: 23).

169 En este sentido, en la ley I, del título XIII, de la Segunda Partida se establecía, respecto del rey, «que el pueblo leal, non deue cobdiciar su muerte, nin quererla ver en ninguna manera», si bien sólo quien expresase paladinamente este deseo encontraría como respuesta un reproche penal, consistente en el destierro. Por otra parte, en diferentes leyes del mismo título se exhortaba a no desear diferentes males que pudieran venir al rey, pero, como analizaremos detenidamente en la siguiente nota, únicamente cuando este deseo se manifestase exteriormente, merecería entonces el infractor un reproche penal.

170 A este respecto, en el título XIII de la Segunda Partida encontramos una serie de leyes que pudieran llevar al error del jurista, dada
Particularmente nos interesan los tabúes configurados en la ley XVIII, del título XIII, del libro II $^{171}$, bajo la obligación del pueblo de honrar al rey, pues en ellos se percibe de una manera evidente la separación simbólica entre la figura del rey y la de sus súbditos. Éstos, de acuerdo con las Partidas, no podían hablar con el rey desde un lugar más elevado, sino que habían de buscar una ubicación inferior y fijar la vista humildemente para entablar conversación con el monarca. Tampoco podían andar o cabalgar a su altura, salvo que fueran llamados expresamente por él, y tenían prohibido acostarse en su lecho o saltar sobre el mismo, entre otras normas que nutrían a este abismo cargado de significado, antes mencionado. Además, se establecía la obligación de no hacer mal o dañar a las imágenes del monarca ni a sus símbolos, bajo las mismas penas que se derivaban del daño al propio rey, lo que no debe extrañarnos puesto que, como ha sido estudiado, las imágenes o representaciones de las cosas sagradas adquieren su misma naturaleza y precisan de unos tabúes que las protejan ${ }^{172}$.

Establecidas las interdicciones o los tabúes necesarios, el legislador se encargó de subvertir los principios penales y procesales establecidos en su propio código para confeccionar una respuesta excepcional ante la mayor transgresión que podían sufrir estas normas. De esta manera, todo hombre podía acusar a otro por el delito de traición, incluso aquellos que no estaban facultados para acusar a nadie en virtud de lo dispuesto en las reglas procesales de carácter general ${ }^{173} \mathrm{y}$, además, respecto de la capacidad procesal pasiva, el traidor podía ser acusado y juzgado aún después de su propia muerte ${ }^{174}$. Entre otras excepciones que podrían mencionarse, ${ }^{175}$ resulta conveniente destacar que, de recaer sentencia condenatoria, no sólo se penaba al traidor, sino que también se imponía una pena sobre

su redacción. En primer lugar, en la ley II se exhortaba a los súbditos a no "cobdiciar, en ninguna manera, oyr la cosa de que le pudiesse venir daño ni muerte, ni deshonrra» al rey. A pesar de esta redacción, entendemos, siguiendo al glosador Gregorio López, que el tipo penal aquí configurado sería el de omisión del deber de interrumpir al que pronunciara tales palabras y no el de codiciar oírlas (cf. López, G. 1576: glosa Lo cobdiciassen a Part 2,13,2). Resulta obligado llegar a esta interpretación si acudimos a lo dispuesto en la ley II, del título XXXI, del libro VII, que establecía el principio general de que no cabía pena por el pensamiento y, además, empleaba como ejemplo el caso de los pensamientos malos sobre la figura del rey. Bajo este mismo criterio hemos de interpretar la ley III, del mismo título XIII, de la Segunda Partida, que castigaba a los que "sabor ouiessen de sentir daño, e deshonrra del Rey su señor». Por tanto, a pesar de su redacción, sólo cuando ese sentimiento se expresase en el fuero externo sería merecedor del reproche penal correspondiente. Finalmente, en la ley VIII del mencionado título se castigaba al que quisiera oír y creyese determinadas palabras en contra del rey. Al igual que en la ley II, entendemos, como Gregorio López, que el tipo penal aquí configurado sería el de omisión del deber de interrumpir al que pronunciara tales palabras (cf. López, G. 1576: glosa Deven ser echados del Reyno a Part 2,13,8, que remite a López, G. 1576: glosa Lo cobdiciassen a Part 2,13,2).

171 Véase el claro antecedente de estas normas en el título II, del libro II del Espéculo.

172 Cf. Durkheim 1968: 107-136.

173 Cf. Part 7,2,3.

174 Cf. ídem. Ésta una de las tres excepciones al principio de que no era posible acusar a los muertos, para las otras dos, cf. Part 7,1,7 y $\mathrm{P}$ 7,25,7, como bien se nos recuerda en Sainz Guerra 2004: 76-77.

175 Sobre este tema, cf. Iturrioz 1955: $74-75$ y Grassotti 1978: 
sus hijos, ${ }^{176}$ de la misma forma que en la Séptima Partida se extendía el castigo por la trayción de matar a Cristo a los judíos del siglo XIII, ${ }^{177}$ lo que nos marca una conexión evidente entre ambos crímenes. Pero, particularmente, nos interesa la ejecución del castigo que correspondía a determinados traidores al rey, en concreto a los que «se trabajassen de su muerte», puesto que se establecía que la pena había de serles aplicada «lo mas cruelmente, e lo mas abiltadamente que puedan pensar», ya que:

Ca los que se trabajassen de su muerte, yrian contra el fecho de Dios, e contra el su mandamiento, que a matarian aquel que el posiera en su lugar en tierra, ca el mismo defendio, que ninguno non metiesse mano en ellos, para fazerles mal. Otrosi farian contra el reyno, ca les quitaria aquella cabeça, que Dios les diera: e la vida porque biuen en vno; e demas darian mala nombradia al Reyno por siempre. E aun farian contra si mismos, matando su señor, a quien deuen guardar sobre todas las cosas deste mundo, e denostar seyan de traycion a ssi e, e todo su linaje, para siempre. ${ }^{178}$

En consecuencia, además de constituirse excepciones a los principios del derecho establecidos en cuanto a la posibilidad de acusar al traidor y a las penas derivadas del delito, también las hallamos en la ejecución de éstas, donde apreciamos una crueldad que interpretamos como una hierofanía ${ }^{179}$ y que se justificaba en la medida en que los súbditos no respetaran las principales prohibiciones que mantenían al rey a salvo, y al propio pueblo, que en él se espejaba. Esta reacción del rey, por otra parte, nos permite comprender en todo su sentido el temor que habían de sentir por él sus súbditos, de igual forma que los fieles habían de temer a la cólera divina, ${ }^{180}$ pues el hombre carece de toda defensa ante el castigo que proviene de lo numínico. ${ }^{181}$

Por último, la protección del rey también se extendía, en distintos grados, sobre su familia, ${ }^{182}$ sus oficiales ${ }^{183}$ y sus bienes, ${ }^{184}$ con la intención, entre otras razones, de evitar el daño al monarca por vías indirectas, lo que cerraba un

176 Cf. Part 2,19,9 y P 7,2,2 (sobre este particular véase también P $7,31,9)$. Esta práctica legislativa de extender la respuesta penal sobre la familia del traidor ya la apreciamos con anterioridad a las Partidas en el derecho alfonsí (cf. Esp 2,1,6) y, respecto del derecho prealfonsí, en algunos fueros de la familia de Cuenca-Teruel (cf. F. Cuenca 975 $(43,12)$, F. Teruel 533 y F. Zorita 858), si bien otros varios de estos fueros establecieron únicamente penas para los traidores al rey y para sus cómplices (cf. C. Valentino 4,13,9, F. Úbeda 89, F. Iznatoraf 869, F. Alcaraz 12,6, F. Alarcón 813, F. Alcázar 813 y F. Andújar 662).

177 Cf. Part 7,24,3. Por su parte, en el Fuero Real se vinculaba expresamente la traición al rey con la rebelión de Lucifer (cf. F. Rea 1,2). En el derecho visigótico encontramos un paralelismo diferente, pero bajo un esquema teológico análogo, pues al traidor al rey se le asemejaba con Judas Iscariote en la ley IX del título preliminar del Liber Iudiciorum.

178 Cf. Part 2,13,6. La necesidad de una pena cruel y aviltada a los traidores también era establecida en Esp 2,6,1.

179 Respecto del concepto de hierofanía, cf. Eliade 1970: 24.

180 Cf. Part 2.12.

181 En este sentido, como vimos, en opinión de G. Bataille, la reacción brutal y sanguinaria era la reacción característica de los que él consideraba como reyes sagrados contra sus enemigos, cf. Bataille 1993: 27.

182 Cf. Part 2,14 y P 2,15.

183 Cf. Part 2,16.

184 Cf. Part 2,17. sistema de protección que, analizado bajo las claves que nos proporciona los estudios de lo sagrado, se nos abre a una interpretación más profunda, en la medida en que descubrimos la naturaleza absolutamente heterogénea del rey, separado simbólicamente de sus súbditos por estos tabúes. Por lo tanto, a esta altura del análisis, no podemos sostener la ausencia de elementos de sacralidad asociados con el rey en las leyes de las Partidas, por el contrario, su naturaleza fue configurada bajo esquemas de plena sacralidad, lo que comprobamos al aplicar a este entramado simbólico no los requisitos propios de otro contexto cultural, sino el criterio durkheimiano de diferenciación entre lo sagrado y lo profano y las aportaciones de otros destacados antropólogos y sociólogos que estudian el mismo fenómeno, en lo que hemos invertido una parte esencial de nuestra explicación en el presente trabajo. Para el revestimiento definitivo de su naturaleza sagrada, el pueblo habría de compartir estas tramas difundidas por la propaganda regia y concienzudamente elaboradas en busca del fortalecimiento del capital simbólico de Alfonso X.

\section{CONCLUSIONES}

A lo largo de este trabajo hemos abordado distintas cuestiones que merecen ser objeto de una reflexión final. En primer lugar, hemos podido comprobar cómo las Partidas confeccionaban un ideal de actuación del rey, como vicario de Dios, que le confería la suficiente maniobrabilidad política en el campo social, ya fuera para castigar con crueldad a determinados malhechores o para aplicar el concepto genérico de justicia según su criterio y en función de las circunstancias. Pero esta arquitectura simbólica no sólo se encontraba en la legislación de Alfonso $X$, sino que sus tramas de significación se hallaban también en la literatura sapiencial promovida por el rey, y ello nos habla claramente de un plan propagandístico destinado a fortalecer su figura. Es en este contexto en el que hemos de insertar las normas del rey para una correcta interpretación de las mismas, sin olvidar los precedentes analizados, que incluso se remontan en la península al período visigodo, y que nos muestran de dónde procedían los cimientos de esta construcción ideológica en España.

Por otra parte, la naturaleza del rey se configurada bajo esquemas de sacralidad, lo que constituía un elemento clave dentro de la estrategia de dominación simbólica emprendida por Alfonso X, y que se hallaba supeditada a la expansión de estas tramas de significación entre su pueblo. En este sentido, y apoyados en las aportaciones de teólogos, sociólogos y antropólogos, hemos comprobado cómo el rey se conformaba en estas normas como si se tratara de una figura numinosa o sagrada, protegido por una serie de leyes que lo amparaban del resto. Un análisis de estas características nos permite, además, comprender el vicariato divino bajo unas herramientas interpretativas adecuadas, así como estudiar la relación emocional que había de desplegar el monarca sobre sus súbditos bajo un fondo simbólico más rico y, finalmente, analizar la reacción violenta y cruel proveniente del vértice del sistema político en el código alfonsí como la respuesta propia del poder sagrado frente a los que pretendían eludir los tabúes establecidos. 


\section{FUENTES JURÍDICAS}

Arboledas Porras, P. A. (ed.) 1994. «El fuero de Sabiote». Cuadernos de Historia del Derecho, 1: 243-441

Arias Bonet, J. A. (ed.) 1975. Primera Partida según el manuscrito Add. 20787 del British Museum. Valladolid: Universidad de Valladolid.

Cortes de los antiguos reinos de León y de Castilla. Tomo I. 1861. Rea Academia de la Historia. Madrid [incluye el Ordenamiento de las Cortes de Valladolid de 1258 y el Ordenamiento de posturas y otros capítulos generales otorgados en el ayuntamiento de Jerez en 1269].

Friedberg, E. (ed.) 1879. Corpus Iuris Canonici. Lipsiae: Bernhard Tauchnitz [incluye el Decreto de Graciano].

García del Corral, I. (trad. y com.). 1895. Cuerpo de derecho civil romano. Barcelona. Disponible en línea en http://biblio.juridicas. unam.mx/cons.htm [Incluye el Digesto y el Código Justiniano]

González, F. A. (ed.) 1850. Colección de cánones de la Iglesia española con notas e ilustraciones de D. Juan Tejada y Ramiro. Madrid: Imprenta de don Anselmo Santa Coloma y Compañía

Gorosh, M. (ed.) 1950. El fuero de Teruel según los Mss. 1-4 de la Sociedad Económica Turolense de Amigos del País y 802 de la Biblioteca Nacional de Madrid. Estocolmo: LHMA

Gutiérrez Cuadrado, J. (ed.) 1979. Fuero de Úbeda. Valencia: Universidad de Valencia

López, G. (ed.) 1576. Las Siete Partidas del Sabio Rey don Alonso el nono nueuamente glosadas por el licenciado Gregorio López. Salamanca: casa de Domingo de Portonarijs Vrsino.

Los códigos españoles concordados y anotados. 1849. Madrid: Imprenta de la Publicidad [incluye el Liber ludiciorum, el Fuero Juzgo, el Fuero Viejo, el Fuero Real, el Espéculo y las Leyes Nuevas]

Luño Peña, E. (ed.) 1927. Legislación foral de don Rodrigo Jiménez de Rada. Zaragoza [incluye el fuero de Brihuega]

Majada Neila, J. (ed.) 1986. Fuero de Plasencia. Introducción, traducción y vocabulario. Plasencia: Ayuntamiento de Plasencia.

Martín Lázaro, A. (ed.) 1926. Fuero castellano de Béjar (siglo XIII). Preliminar, transcripción y notas. Madrid: Tipografía de Archivos.

Martín Palma, M. T. (ed.) 1984. Los fueros de Villaescusa de Haro y Huete. Málaga: Universidad de Málaga.

Quesada Huertas, P. (ed.) 2006. El fuero de Andújar: Estudio y edición. Jaén: Universidad de Jaén.

Partidas. 1807. Madrid: Real Academia de la Historia.

Roudil, J. (ed.) 1962. El fuero de Baeza. Edición, estudio y vocabulario. La Haya: Van Goor Zonen.

Sánchez, G. (ed.) 1919. Fueros castellanos de Soria y Alcalá de Henares. Madrid: Centro de Estudios Históricos.

Sancho Izquierdo, M. (ed.) 1968. Les fueros d'Alcaraz et d'Alarcón. Edition synoptique avec les variantes du Fuero d'Alcaraz, introductiom, notes et glossaire. París: Centre de Philologie et de littératurs romanes de la Faculté des Lettres et Sciences Humanes de Strasburg.

Ureña y Smenjaud, R. de (ed.) 1935. Fuero de Cuenca (formas primitiva y sistemática: Texto castellano y adaptación al fuero de Iznatoraf). Madrid. Tipografía de archivos.

Ureña y Smenjaud, R. de (ed.) 1911. Fuero de Zorita de los Canes según el códice 217 de la Biblioteca Nacional (siglos XIII al XIV) y sus relaciones con el fuero latino de Cuenca y el romanceado de Alcázar. Madrid: Establecimiento tipográfico de Fortanet.

Vanderford, K. H. (ed.) 1945. El Setenario. Buenos Aires: Instituto de Filosofía.

\section{OTRAS FUENTES LITERARIAS}

Bandak, C. (ed.) 2007. Libro de los buenos proverbios. Estudio y edición crítica de las versiones castellana y árabe. Zaragoza: Instituto de Estudios Islámicos y del Oriente Próximo.

Bizzarri, H. O. (ed.) 1997. «Flores de filosofía, manuscrito escurialense S.II.13». Memorabilia: boletín de literatura sapiencia 1.

Bizzarri, H. O. (ed.) 2010. Secreto de los secretos y Poridat de las poridades. Valencia: Universidad de Valencia.
Bocados de oro. 1510. Toledo. Disponible en línea en http://books. google.es/

Döhla, H. J. (ed.) 2007. El libro de Calila e Dimna (1251). Edición nueva de los manuscritos castellanos, con una introducción intercultural y un análisis lexicográfico árabe-español. Zurich: Universidad de Zurich.

Gassó, H. H. y Romero Lucas, D. (eds.). 2002. «Libro de los doce sabios, Ms. 92 (=77) de la Biblioteca Menéndez Pelayo de Santander». Memorabilia: boletín de literatura sapiencia 6.

Haro Cortés, M. (ed.) 1998. Libro de los cien capítulos (dichos en palabras breves e complicadas). Fankfurt-Madrid: Vervuert-Iberoamericana.

Haro Cortés, M. (ed.) 2013. «Dichos y castigos de sabios: compilación de sentencias en el manuscrito 39 de la colección San Román (Real Academia de la Historia)». Revista de Literatura Medieval 25: 11-38.

Hilty, G. (ed.) 1954. El libro conplido en los iudizios de las estrellas. Madrid: Real Academia Española.

Kasten, L. A. y Kiddle, L. B. (eds.) 1961. Libro de las Cruzes. Madrid: Instituto Miguel de Cervantes.

Lucía Mejía, J. M. (ed.) 1997. «Flores de filosofía, manuscrito 9428 BNM». Memorabilia: boletín de literatura sapiencia 1.

Mettmann, W. (ed.) 1981. Cantigas de Santa María de Alfonso X el Sabio. Vigo: Edicións Xerais de Galicia.

Mettmann, W. (ed.) 1987. «Eine Altspanische Gnomensammlung. Dichos de los sabios", en Homenaje a Alvaro Galmés de Fuentes, III: 493-513. Madrid: Gredos.

Menéndez Pidal, R. (ed.) 1906. Primera crónica General de España: Estoria de España que mandó componer Alfonso el Sabio y se continuaba bajo Sancho IV en 1289. Madrid: Bailly-Bailliere e hijos, editores.

Nova Vulgata. Disponible en línea en http://www.vatican.va/latin/ latin_bible.html

[Peraldo, G.] «De eruditione principum», en Tomás de Aquino, Santo. 1864. Opera omnia. Parma. Disponible en línea en http://www. corpusthomisticum.org/iopera.html

Salisbury, J. de 1984. Policratus, Madrid: Editora Nacional.

Sánchez-Prieto, B. (ed.) 2009. General Estoria. Madrid: Fundación José Antonio de Castro.

Sánchez-Prieto, B. (ed.) 2014. Lapidario; Libro de las formas e imágenes que son en los cielos. Madrid: Fundación José Antonio de Castro.

Tomás de Aquino, Santo 1861. El gobierno monárquico o sea El libro De Regimine Principum. Sevilla: Imprenta y librería de D. A. Izquierdo.

Uría Maqua, I. y González Álvarez, J. (eds.) 2002. El libro de los doce sabios y Relación de los reyes de León y Castilla. Códice ovetense. Oviedo: Universidad de Oviedo.

\section{BibliografíA}

Alcorta, C. S. y Sosis, R. 2005. "Ritual, emotion and sacred symbols». Human Nature 16: 323-359.

Bango Torviso, G. I. 2010-2011. «La imagen pública de la realeza bajo el reinado de Alfonso X. Breves apostillas sobre regalía, insignia y actuaciones protocolarias». Alcanate 7: 13-42.

Bataille, G. 1993. El Estado y el problema del fascismo. Valencia: Pretextos G.

Bazán, I. 2008. «El modelo de sexualidad de la sociedad cristiana medieval: norma y transgresión». Cuadernos del CEMYR 16: 167-192.

Bermejo Cabrero, J. L. 1975. "Principios y apotegmas sobre la ley y el rey en la Baja Edad Media castellana Bermejo». Hispania 35: 31-47.

Bizzarri, H. O. 1995. "Las colecciones sapienciales castellanas en el proceso de reafirmación del poder monárquico (siglos XII y XIV)». Cahiers d'Études Hispaniques Médiévales 20: 35-74.

Bloch, M. 2006. Los reyes taumaturgos. México D. F: Fondo de cultura económica.

Boureau, A. 1992a. "Droit et théologie au XIIle siècle». Annales. Histoire, Sciences Sociales 47: 1113-1125. 
Boureau, A. 1992b. «Un obstacle a la sacralité royale en Occidenté. Le príncipe hiérarchique», en A. Boureau y C. L. Ingerflom (ed.), La royauté sacrée dans le monde chrétien, (Colloque de Royaumont, marzo de 1989): 29-37. Paris: EHESS.

Bourdieu, P. 1993. «Esprits d'Etat. Genèse et structure du champ bureaucratique». Actes de la recherche en sciences sociales 96: 49-62.

Bourdieu, P. 1997. Razones prácticas sobre la teoría de la acción. Barcelona: Anagrama.

Brundage, J. A. 2000a. La ley, el sexo y la sociedad cristiana en la época medieval: 381-382 Chicago: University of Chicago.

Brundage, J. A. 2000b. "Sex and canon law», en V. L. Bullough y J. A. Brundage (eds.), Handbook of medieval sexuality: 33-51. Nueva York: Routledge.

Caillois, R. 1984. El hombre y lo sagrado. México D. F.: Fondo de cultura económica.

Canning, J. M. 1980. «The corporation in the political thought of the italian jurist of the thirteenth and fourteenth centuries». History of Political Theory 1: 9-32.

Canning, J. M. 1993. A History of medieval political thought. LondresNueva York: Routledge.

Canning, J. M. 2008. «Law, sovereignty and corporation theory, 13001400", en J. H. Burns (ed.), The Cambridge History of Medieval Political Thought c. 350-c.1400: 454-476. Cambridge: Cambridge University Press.

Colberty Rhodes, R. 1978. «Emile Durkheim and the historical thought of Marc Bloch». Theory and Society 5-1: 45-73.

Chroust, A. H. 1947. "The corporate idea and the body politic in the Middle Ages». Review of Politics 9: 423-453.

Coleman, E. B. y White, K. 2006. "Stretching the sacred", en Negotiating the Sacred: Blasphemy and Sacrilege in a Multicultura Society: 65-78. Camberra: ANU E Press.

Delgado Valero, C. 1993-1994. "La corona como insignia de poder durante la Edad Media». Anales de historia del arte 4: 747-764.

Durkheim, E. 1968. Las formas elementales de la vida religiosa. Buenos Aires: Shapire.

Durkheim, E. 1995. La división del trabajo social. Madrid: Akal.

Domínguez, A. 2008-2009. "Retratos de Alfonso X el Sabio en la Primera Partida (British Library, Add. ms.20.787). Iconografía y cronología». Alcanate 6: 239-251.

Eliade, M. 1970. Tratado de las religiones I. Madrid: Cristiandad.

Eliade, M. 2010. Mitos, sueños y misterios. Barcelona: Kairos.

Ferreiros, A. 1971. Historia de la traición. La traición regia en León y Castilla. Santiago de Compostela: Universidad de Santiago de Compostela.

Ferrari, A. 1934. "La secularización de la teoría del Estado en las Partidas». Anuario de historia del derecho español 11: 449-456.

Foronda, F. 2005-2006. "Sociedad política, propaganda monárquica y régimen en la Castilla del siglo XIII: en torno al Libro de los doze sabios». Edad Media: revista de historia 7: 13-36.

Foronda, F. 2013. El espanto y el miedo. Golpismo, emociones políticas y constitucionalismo en la Edad Media. Madrid: Dykinson.

Foucault, M. 1995. La verdad y las formas jurídicas. Barcelona: Gedisa, 1995.

Fournés, G. 2002. "Un motivo cidiano en la obra de Alfonso X: La ira regia», en Alvar, C., Gómez, F. y Martin, G. (eds.) El Cid: de la materia épica a las crónicas caballerescas: actas del Congreso Internacional «IX Centenario de la Muerte del Cid», celebrado en la Univ. de Alcalá de Henares: los días 19 y 20 de noviembre de 1999 284-294. Alcalá de Henares: Universidad de Alcalá.

Gacto, E. 1971. «La filiación ilegítima en la historia del derecho español». Anuario de Historia del Derecho 41: 899-944.

García-Pelayo, M. 1959. El reino de Dios, arquetipo político: estudio sobre las formas políticas de la Alta Edad Media. Madrid: Revista de Occidente.

García-Pelayo, M. 2009. "La transfiguración del poder», en Obras completas: 2447-2470. Madrid: Centro de Estudios Políticos y Constitucionales.
Garland, D. 2006. Castigo y sociedad moderna. Un estudio de teoría social. Madrid: Siglo XXI.

Geertz, C. 1985. "Centers, kings, and charisma: Reflections on the symbolics of power", en S. Wilentz, Rites of poer. Symbolism, ritual and politics since the Middle Ages: 13-38. Filadelfia: University of Pennsylvania.

Geertz, C. 2003. La interpretación de las culturas. Barcelona: Gedisa.

González Alonso, B. 1988. «Poder regio, Cortes y régimen político en la Castilla Bajomedieval (1252-1474)», en Las Cortes de Castilla y León en la Edad Media, v.2: 201-254. Valladolid: Cortes de Castilla y León.

Grassotti, H. 1978. "La ira regia en León y Castilla», en Miscelánea de Estudios sobre Instituciones castellano-leonesas. Bilbao: Editorial Nájera.

Grein, E. 2010. «Isidoro de Sevilla y los fundamentos de la realeza cristiana en la Hispania visigoda (siglo VII)». Miscelánea Medieval Murciana 34: 23-32.

Haro Cortés, M. 1996. La imagen del poder real a través de los compendios de castigos castellanos del siglo XIII. Londres: Queen Mary and Westfield College.

Haro Cortés, M. (ed.) 1998. Libro de los cien capítulos (dichos en palabras breves e complicadas). Madrid: Iberoamericana Editorial Veruert.

Harris, M. 1976. "History and Significance of the Emic/Etic Distinction». Annual Review of Anthropology 5: 329-350.

Hunt, L. 2001. "The sacred and the French Revolution», en W. S. F., Pickering (ed.), Emile Durkheim: Critical Assessments of Leading Sociologists, v.2: 74-91. Londres: Routledge.

Iturrioz, J. 1955, «Fundamentos sociológicos en las Partidas de Alfonso $\mathrm{X}$ el Sabio», en C. Viñas y Mey (dir.), Estudios de Historia social de España, III: 3-100. Madrid: CSIC.

Kantorowicz, E. H. 1985. Los dos cuerpos del rey. Un estudio de teología política medieval. Madrid: Alianza Editorial.

Kleine, M. 2014a. «Imágenes del poder real en la obra de Alfonso X (I): Rex christianus». De Medio Aevo 3-1: 1-42.

Kleine, M. 2014b. «Imágenes del poder real en la obra de Alfonso X (II): Rex iustus». De Medio Aevo 3-2: 39-80.

Leeuw, G. van der 1964. La fenomenología de la religión. MéxicoBuenos Aires: Fondo de cultura económica.

Liebeschütz, H. 1950. Mediaeval Humanism in the Life and Writings of John of Salisbury. Londres: Warburg Institute.

Linehan, P. 2011. Historia e historiadores de la España medieval. Salamanca: Universidad de Salamanca

López, J. 2003. "La imago regis en las Partidas alfonsinas». Saberes: Revista de estudios económicos, jurídicos y sociales 1.

López-Amo, A. 1956. «El derecho penal español de la Baja Edad Media». Anuario de historia del derecho español 26: 337-368.

Macdonald, R. A. 1984. "Problemas políticos y derecho alfonsino considerado desde tres puntos de vista». Anuario de Historia del Derecho Español 54: 25-54.

Macdonald, R. A. 1987. "Alfonsine Law, the Cantigas, and Justice», en I. J. Katz y J. Keller (eds.), Studies on the Cantigas de Santa Maria: Art, Music, and Poetry: 313-327. Madison: Hispanic Seminary of Medieval Studies.

Madero, M. 1996. «Formas de la justicia en la obra jurídica de Alfonso X el Sabio». Hispania: Revista española de historia 56, 193: 447-466.

Maravall, J. A. 1999a. «Del régimen feudal al régimen corporativo en el pensamiento de Alfonso X», en Estudios de historia del pensamiento español, I: 89-136. Madrid: Centro de estudios políticos y constitucionales.

Maravall, J. A. 1999b. «La idea de cuerpo místico en España antes de Erasmo", en Estudios de historia del pensamiento español, v. I: 169-189. Madrid: Centro de estudios políticos y constitucionales.

Marey, A. 2014. «El rey, el emperador, el tirano: el concepto del poder e ideal político e la cultura intelectual alfonsina». Cuadernos de Historia del Derecho 21: 229-242.

Martin, G. 1995. «Alphonse X ou la science politique. (Septénaire, 1-11)». Cahiers de linguistique hispanique médievale 20: 7-34. 
Martin, G. 2000. «Alphonse X de Castille, roi et empereur. Commentaire du premier titre de la Deuxième Partie». Cahiers de linguistique hispanique médiévale 23: 323-348.

Martínez, F. 2010. «Ecos cronísticos del rey-juez medieval». Cuadernos de Historia del Derecho ext. 2: 303-356.

Morín, A. 2007. "Muertos y pecados en la primera Partida». Anuario del Centro de Estudios Históricos Prof. Carlos S. A. Segreti 7-7 (2007): 371-390.

Morín, A. 2009. Pecado y delito en la Edad Media. Estudio de una relación a partir de la obra de Alfonso el Sabio. Córdoba: Ediciones del copista.

Nanu, I. 2002. "Las dos espadas del mundo. Algunas notas sobre e prólogo de la Segunda Partida». Memorabilia: boletín de literatura sapiencial 6.

Nanu, I. 2013. La Segunda Partida de Alfonso X el Sabio y la tradición de los Specula Principum. Tesis doctoral, Universitat de València.

Nieto Soria, J. M. 1986. "Las imágenes religiosas y del poder real en la Castilla del siglo XIII». En la España medieval 19: 709-730.

Nieto Soria, J. M. 1988. Fundamentos ideológicos del poder real en Castilla. Madrid: Eudema.

Nieto Soria, J. M. 1989. "Principios teóricos y evolución de la teoría eclesiástica de Alfonso X». Mayurqa: revista del Departament de Ciències Històriques i Teoria de les Arts 22-1: 465-474.

Nieto Soria, J. M. 1997. «Origen divino, espíritu laico y poder real en la Castilla del siglo XIII». Anuario de estudios medievales 27: 43-102.

Nieto Soria, J. M. 2005. «Rex inutilis y tiranía en el debate político de la Castilla bajomedieval», en F. Foronda, J. P. Genet, y J. M. Nieto Soria (dirs.), Coups d'État à la fin du Moyen Âge? Aux fondements du pouvoir politique en Europe occidentale: 73-92. Madrid: Casa Velázquez.

Nieto Soria, J. M. 2006. "La monarquía como conflicto de legitimidades», en La monarquía como conflicto en la corona castellano-leonesa (c. 1230-1504). Madrid: Silex.

Nogales, D. 2006. "Los espejos de príncipes en Castilla (siglos XIII-XV): Un modelo literario de la realeza bajomedieval». Medievalismo: Boletín de la Sociedad Española de Estudios Medievales 16: 9-40.

O'Callaham, J. F. 1999. El rey sabio. El reinado de Alfonso X en Castilla. Sevilla: Universidad de Sevilla.

Orlandis. J. 1947. «Las consecuencias del delito en el derecho de la Alta Edad Media». Anuario de Historia del Derecho Español 18: 61-165.

Otto, R. 1965. Lo santo. Lo racional y lo irracional en la idea de Dios. Madrid: Revista de Occidente.

Panateri, D. 2015a. "La ley en las Siete Partidas». eHumanista 31 711-727.

Panateri, D. 2015b. «Las dos espadas y el vicariato divino en Siete Partidas». Lemir 19: 265-279.

Pérez de Tudela, M. I. 1991. "Ideario político y orden social en las Partidas de Alfonso X». En la España Medieval 14: 183-200.

Pérez de Tudela, M. I. 1992. "La imagen de la virgen María en las Cantigas de Alfonso X». En la España Medieval 15: 297-320.

Pérez Martín, A. 1992. "Fuentes romanas en Las Partidas». Glossae. Revista de historia del derecho europeo 4: 215-246.

Post, G. 2006. Studies in medieval thought. Public law and the state, 1100-1322. Nueva Jersey: The Lawbook Exchange LTD.
Ramp, W. 2010. «Durkheim and after. Religion, culture and politics», en B. S. Turner (ed.), The New Blackwell Companion to the Sociology of Religion: 52-75. Singapur: Wiley-Blackwell.

Rodríguez Gil, M. 1998. Vice uxor. Notas sobre el concubinato en España desde la Recepción del Derecho común. Madrid: Universidad Complutense de Madrid.

Rucquoi, A. 1992. "De los reyes que no son taumaturgos: los fundamentos de la realeza en España». Estudios de Historia y Sociedad 13-51: 55-100.

Rucquoi, A. y Bizzarri, H. O. 2005. "Los espejos de príncipes de Castilla: Entre Oriente y Occidente». Cuadernos de Historia de España 79: 9-30.

Ruíz, T. F. 1985. "Unsacred monarchy: The kings of Castile in the late Middle Ages», en S. Wilentz (ed.), Rites of power. Symbolism, ritual, and political since the Middle Ages: 109-144. Filadelfia: Univertity of Pennsylvania.

Ruíz Gómez, F. 2008. "La ilusión de la identidad en el imaginario medieval según las Partidas». Edad Media: revista de historia 9: 239-261.

Sainz Guerra, J. 2004. La evolución del derecho penal en España. Jaén: Universidad de Jaén.

Sánchez-Arcilla, J. 2008-2009. «La teoría de la ley en la obra legislativa de Alfonso X el Sabio». Alcanate 6: 81-123.

Serra Ruíz, R. 1962-1963. "La finalidad de la pena en la legislación de las Partidas». Anales de la Universidad de Murcia 3-4: 199-257.

Shils, E. 1965. "Charisma, order, and status». American Sociological Review 30-2: 199-213.

Tomás y Valiente, F. 1969. El derecho de la monarquía absoluta. Madrid: Tecnos.

Torrent, A. 2013. «La recepción del derecho justinianeo en España en la Baja Edad Media (siglos XII-XV). Un capítulo en la historia del derecho europeo». RIDROM: Revista internacional de derecho europeo 10: 26-119.

Ubieto Arteta, A. 1991. Orígenes de los reinos de Castilla y Aragón. Zaragoza: Universidad de Zaragoza.

Ullmann, W. 1944. "The influence of John of Salisbury on medieval italian jurists». The English Historical Review 49: 383-392.

Ullmann, W. 1985. Principios de gobierno y política en la Edad Media. Madrid: Alianza Editorial.

Ullmann, W. 1999. Historia del pensamiento político en la Edad Media. Ariel: Barcelona.

Villarroel González, O. 2008. «El crimen político en la Baja Edad Media: entre la oposición política y el delito. Primera parte. Estudio». Clío \& Crimen: Revista del Centro de Historia del Crimen de Durango 5: 267-374.

Walmisley-Santiago, G. V. 1993. "Alfonso el Sabio and Justice: Las Siete Partidas, the Cantigas de Santa Maria, and Calila e Dimna». Anuario Medieval 5: 151-164.

Watts Miller, W. 1996. Durkheim, morals and modernity. Abingdon: Routledge.

Weber, M. 1964. Economía y sociedad. México D. F.-Madrid: Fondo de cultura económica.

Widengren, G. 1976. Fenomenología de la religión. Madrid: Ediciones Cristiandad. 